Article

\title{
Change of the Rainfall Seasonality Over Central Peruvian Andes: Onset, End, Duration and Its Relationship With Large-Scale Atmospheric Circulation
}

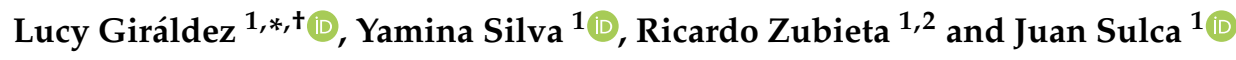 \\ 1 Instituto Geofísico del Perú (IGP), Lima 15012, Peru; fsilva@igp.gob.pe (Y.S.); rzubieta@igp.gob.pe (R.Z.); \\ jsulca@igp.gob.pe (J.S.) \\ 2 Universidad Nacional Agraria la Molina (UNALM), Programa de Doctorado en Recursos Hídricos, Lima \\ 15024, Peru \\ * Correspondence: lgiraldez@igp.gob.pe; Tel.: +51-9-9001-5171 \\ † Current address: Calle Badajoz 169 Urb. Mayorazgo IV Etapa, Ate, Lima 15012, Peru.
}

Received: 5 January 2020; Accepted: 20 January 2020; Published: 28 January 2020

\begin{abstract}
Changes of the onset dates, end dates, and duration of the rainy season over central Peruvian Andes (Mantaro river basin, MRB) could severely affect water resources management and the main economic activities (e.g., rainfed agriculture, raising cattle, among others). Nonetheless, these changes have not been documented for the Tropical Andes. To asses that, we used daily datasets of observed rainfall during the 1965-2013 period. For this period, the average onset (end) date of the rainy season over the MRB occurs in the pentad 17 (19-23 September) [pentad 57 (7-11 April)]. The duration of the rainy season mainly is modulated by the onset dates due to it has higher variability than end dates. There is a reduction of 3 days/decade in the duration of wet season over the MRB for the last four decades due to the delay of the onset days. Furthermore, El Niño favors late-onset and early end of the rainy season, while La Niña favors early onset and late end of the rainy season in the MRB. Onset dates are related to the propagation of the convective region of the South American Monsoon System (SAMS), from the Caribbean region toward the central Amazon basin. Early (late)-onset days are associated with a southward (northward) shift of the South Atlantic Convergence Zone (SACZ) and weak (strong) convection over equatorial Atlantic that induces the southernmost propagation (eastward shift) of the SAMS.
\end{abstract}

Keywords: rainy season duration; onset and end dates; central Peruvian Andes; rainfall seasonality; Mantaro river basin

\section{Introduction}

The precipitation plays a vital role in the hydrological cycle, thus it is one of the climate variables with more attention for climate scientists [1]. Climate change has modified the magnitude, the seasonal distribution and interannual variability of rainfall in the world [2]. The variation of the hydrological cycle due to climate change is one aspect very relevant for humans [3].

The precipitation seasonality is essential for the development of several economic activities in the central Peruvian Andes (e.g., agriculture, hydrologic power generation, and potable water) [4]. There are many pieces of evidence about the change of rainfall regime. The Mantaro valley presented a reduction of the precipitation amount $(-5.6 \mathrm{~mm} /$ decade $)$ over the last decade [5]. The declining of the rainfall amount is consistent with the reduction of the rains between July and October that has provoked a deficiency of the water availability for the irrigation of local crops in the Mantaro 
river basin (MRB) [6]. The lack of water availability in the MRB is intensely increasing due to the $60 \%$ reduction in glacier cover of the central-east part of the glacier system over the MRB between 1976 and 2006 [7]. The retreat of glacier cover will continue in the next two decades and hence the reduction of the water availability will become more severe [8]. All these studies support the change of frequency and seasonal distribution of rain days over the MRB (e.g., a large amount of rainfall falls in few consecutive days, and the small percentages of total annual precipitation may fall into a long period of days) [9].

The onset of the rainy season is the most decisive factor in the rainfed agriculture of the MRB. Farmers use the onset of the rainy period as an indicator to start sowing the land. Advances or delays in the onset of the rainy seasons represent significant climate limitations for agriculture and water storage in reservoirs of the MRB. There are many studies about the onset of the rainy season in South America, mostly in the Amazon basin. The central Amazon presents the largest variation of the onset dates than the rest of the regions of the Amazon basin [10]. For instance, there is a delay in the onset of rains over the Amazon of 2-3 pentads (PENs) during the austral summer of 2015 [11]. The wet-season length in Southern Amazonia has decreased primarily due to a delay in the ending dates of the dry season [12]. In $17 \%$ of the years, onset happened later and in $11 \%$, it happened earlier for central and southeastern Brazil during the period 1984-2004 [13]. Additionally, models simulations have been carried out by $[3,14,15]$, where it was found that onset dates are delayed by some PENs [15]. There will be a robust delay in onset and shortening of rainy seasons for all of tropical Africa and north-east Brazil under $1.5^{\circ} \mathrm{C}$ and $2.0^{\circ} \mathrm{C}$ warming [3]. Few studies have been done for the Andes of Peru. Silva and Mosquera [16] found a delay of 26.3 days of the rainy season over the central zone of the MRB during the 1921-2010 period; however, they could not verify this rainy season delay in the rest of the MRB.

Several studies found that local factors are more relevant in the spatial distribution of the precipitation than large-scale forcings [17]. For instance, [18,19] found that rainfall tends to decrease with altitude, although they have no linear relationship. In MRB, the average of the correlation between altitude and precipitation amount is low $(\mathrm{r}<0.26)$, although the correlation increases in stations located at low altitude and even at an altitude higher than 2500 masl (e.g., $\mathrm{r}<-0.51$ and $\mathrm{r}<0.59$, respectively) [20].

El Niño-Southern Oscillation (ENSO) modulates the precipitation over the central Peruvian Andes [4,21]. El Niño (i.e., the warm phase of ENSO) inhibits austral summer precipitation over the central Peruvian Andes while La Niña (i.e., cold phase of ENSO) favors the austral summer precipitation in this same region [21]. Moreover, Silva et al. [4] found a weak correlation $(-0.3<\mathrm{r}<0.3)$ between Niño 4 index and precipitation over MRB between September and December for the 1960-2004 period. However, there are few studies about the influence of the Sea Surface Temperature (SST) over the Pacific and Atlantic Oceans on the climatological characteristic of the rainy season in the central Andes of Peru (e.g., onset dates, end dates, and duration).

Researches about changes in rainfall seasonality is a priority in the Andean region due to the local farmer's percept delays at the beginning of the rainy season over the entire MRB [22]. Therefore, the aim of this study is the documentation of the climatological characteristic changes of the seasonal rainfall cycle (e.g., onset, termination, and duration) over MRB for the 1965-2013 period. This study also aims to characterize the regional atmospheric circulation patterns associated with the climatological characteristics of the rainy season over MRB. The results will serve to develop monitoring and forecast systems of the rainy season's onset could help farmers adapt to climate change and even prevent future damage to local agriculture.

The paper is structured as follows: Section 2 presents the study area, the scientific background, all datasets, and methods used in the study. The main results and discussions about the change of the rainfall characteristic and trend over the central Peruvian Andes are presented in Section 3. Finally, Section 4 shows the main conclusions of this study. 


\section{Materials and Methods}

\subsection{Study Area}

The MRB is located in the central Peruvian Andes $\left(73^{\circ} 55^{\prime} 00^{\prime \prime}-76^{\circ} 40^{\prime} 30^{\prime \prime} \mathrm{W} ; 10^{\circ} 34^{\prime} 30^{\prime \prime}-13^{\circ} 35^{\prime} 30^{\prime \prime}\right.$ S), with a drainage area of $34,550 \mathrm{~km}^{2}$. The basin partially covers territories of the Junín, Pasco, Huancavelica, and Ayacucho regions. The altitude of the MRB varies between 500 and 5300 masl., and its mean altitude is around 3870 masl (Figure 1). Approximately $70 \%$ of the total surface of the MRB depends on rainfed agriculture. The MRB is the primary source of farm products to several cities in Peru such as the capital city Lima [23,24].

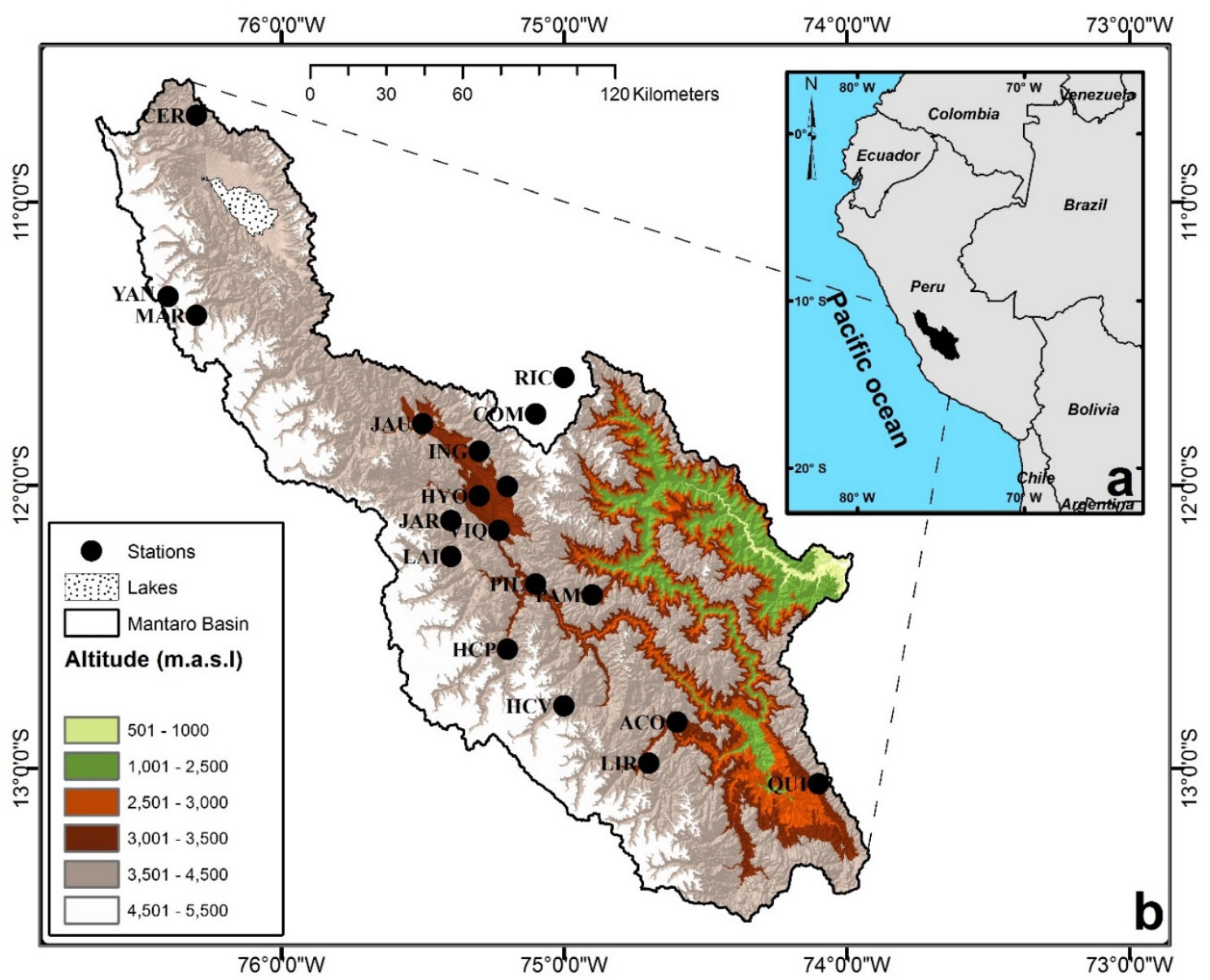

Figure 1. Location of the Mantaro river basin (MRB). Black dots represent the location of all stations used in this study. Shading represents the topographic elevation in the MRB.

The rainy season over MRB features a well-defined annual cycle, a dry season (April-August) and a rainy season (September-March, which is the growing period for local crops) [4,19]. The first rains fall sporadic in early September. The amount of rainfall increases progressively as well as strengthens its intensity in the following months until to reach its peaks in the austral summer (January-March). Conversely, precipitation presents a sharp reduction in April $[4,19,24]$. Thus, almost $83 \%$ of the annual rainfall occurs during the rainy season [20].

The average of the annual precipitation is lower than $1600 \mathrm{~mm} /$ year along the MRB, the highest accumulation of rainfall is observed over the eastern part of the basin, in the jungle of the departments of Junín and Huancavelica [20] (Figure 2). The low precipitations fall over vast spaces of the central and southern zone of MRB. The high rainfall in the northwestern and southwestern parts of MRB in the austral summer is related to orographic rainfall that is due to the transport of warm and moist 
winds from the Amazon basin. For the dry months (June and August) rainfall is almost negligible throughout the basin, except for the eastern region [24].

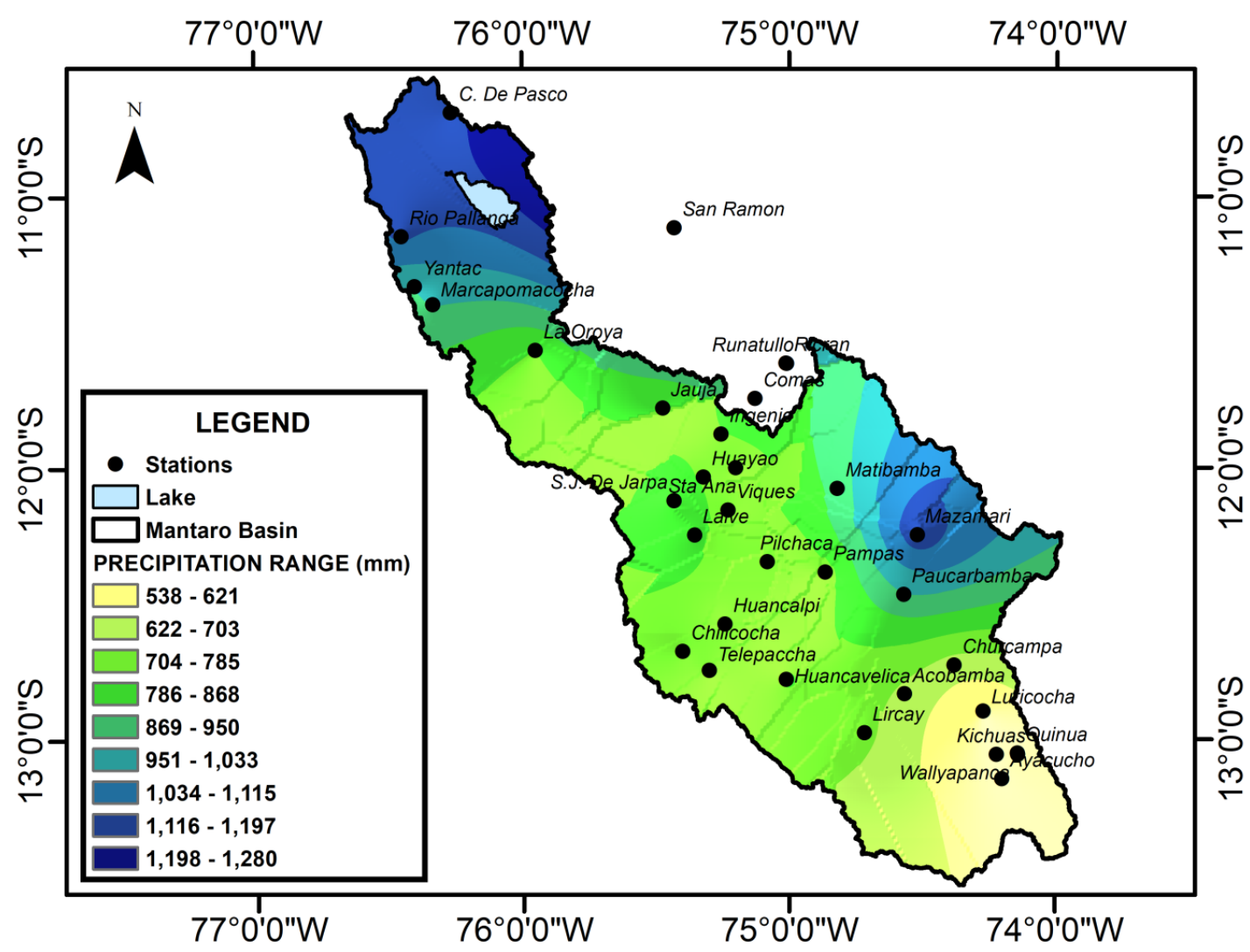

Figure 2. Average annual precipitation in the MRB from 1981 to 2010.

\subsection{Background}

The South American Monsoon System (SAMS) is one of the major monsoon systems in the Southern Hemisphere [25]. The SAMS shows a seasonal cycle with an onset during October, a mature phase between December and February, and demise in April $[10,13,26]$. SAMS onsets start during the austral spring (September-October-November, SON) (Figure 3) when the region of intense convection spreads rapidly from the Caribbean and northwestern South America toward southern Amazon basin and Brazilian highlands in October and southeast Brazil in November [13,26-28]. It is consistent with a strengthening of the humidity influx induced by the change of direction of the low-level cross-equatorial flow in the eastern flank of the northern Andes Mountains in early October [29]. In the upper troposphere, $200 \mathrm{hPa}$, Figure $3 \mathrm{c}$ displays the predominance of westerly wind over South America south of $12^{\circ} \mathrm{S}$ but even cross the southern Atlantic Ocean. Figure $3 \mathrm{c}$ also shows an anticyclonic circulation over the western Amazon basin $\left(66^{\circ} \mathrm{W}, 9^{\circ} \mathrm{S}\right)$ while a cyclonic circulation is observed over the northwest of northeastern Brazil $\left(42^{\circ} \mathrm{W}, 4^{\circ} \mathrm{S}\right)$. During the austral summer (December-January-February, DJF), there is maximum precipitation and is located over the south-central Amazon (Figure 3b). It is known as the mature phase of the SAMS [26,30,31].

The onset of SAMS has received considerable attention. It is evidenced by the developing of many indices to determine the onset and end of the SAMS [26,32-34]. Silva and Carvalho [32] defined an index called Large-scale Index for the South American Monsoon System (LISAM), which is based on a combination of Empirical Orthogonal Function (EOF) of precipitation and various thermodynamic and dynamic low-level fields. Silva and Carvalho [32] found that the onset occurs in the pentad (PEN) 60 and the end date in PEN 24. Gan et al. [33], who used a zonal wind index, found an earlier onset and end than does LISAM (PEN 58 and PEN 22, respectively). Rai and Cavalcanti [13] used the moisture 
flux, found the same onset date than in LISAM but an early end date. However, there are no studies that used the same or quite similar indices for the identification of the onset, end, and duration of the precipitation in MRB.

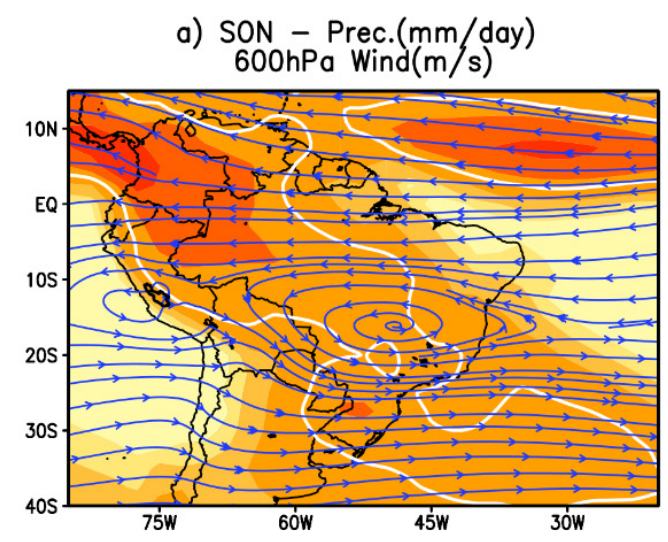

c) $\mathrm{SON}-200 \mathrm{hPa}$ Wind $(\mathrm{m} / \mathrm{s})$

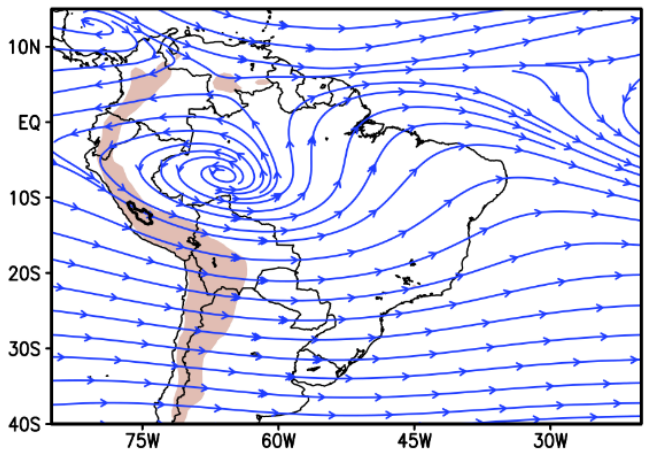

b) DJF - Prec.(mm/day) $600 \mathrm{hPa}$ Wind $(\mathrm{m} / \mathrm{s})$

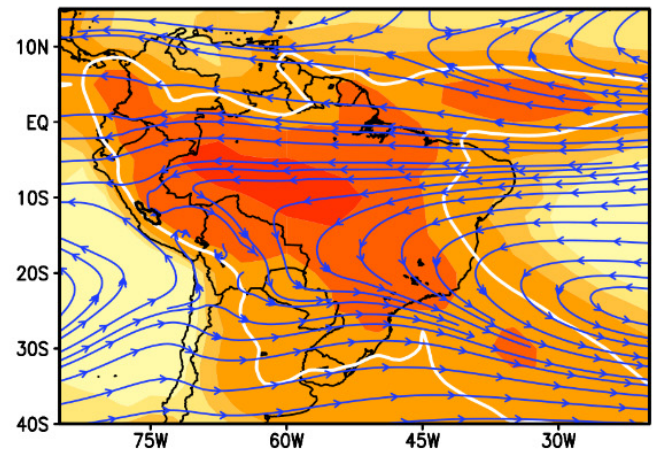

d) DJF - 200hPa Wind $(\mathrm{m} / \mathrm{s})$

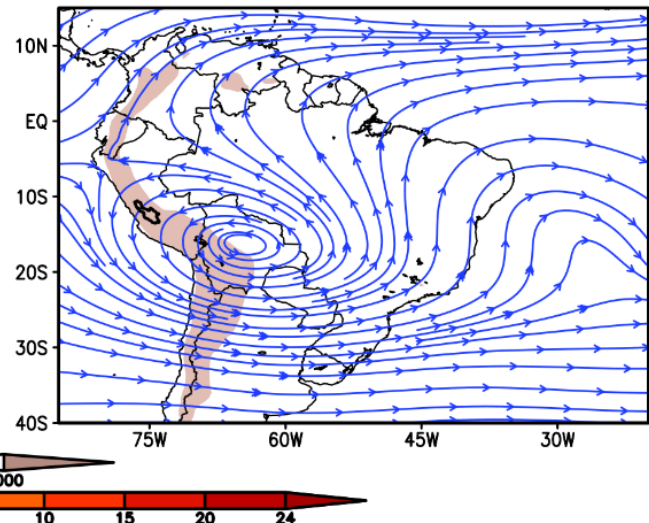

Figure 3. Climatology of $(\mathbf{a}, \mathbf{b})$ precipitation $\left(\mathrm{mm} \mathrm{day}^{-1}\right.$, red shading) and $600 \mathrm{hPa}$ wind $\left(\mathrm{m} \mathrm{s}^{-1}\right.$, streamlines) and (c,d) $200 \mathrm{hPa}$ wind $\left(\mathrm{m} \mathrm{s}^{-1}\right.$, streamlines) during (a,c) austral spring (SON) and (b,d) austral summer (DJF). White contour represents the climatological isoline of $4 \mathrm{~mm} \mathrm{day}^{-1}$. Black contour represents the boundary of the MRB. ERA-Interim reanalysis and Global Precipitation Climatology Project (GPCP) precipitation datasets were used for the 1981-2010 period. Brown shading represents the topographic elevation above $1000 \mathrm{~m}$.

The austral summer rainfall over MRB is associated with $200 \mathrm{hPa}$ easterly zonal wind, although few rainy episodes occur during $200 \mathrm{hPa}$ westerly zonal wind [35]. These upper-level easterly zonal winds uplift warm and moist air from the Amazon Basin to central Peruvian Andes [35,36]. The intensification of easterly zonal winds is associated with the strengthening of an anticyclonic circulation called Bolivian High (BH) [37]. At the same time, an oblique band of precipitation extends between eastern Brazil and the southern Atlantic Ocean called South Atlantic Convergence Zone (SACZ), which registers its maximum peaks in austral summer [38]. Avalos et al. [36], also documented that the strengthening of $\mathrm{BH}$ and SACZ might induce torrential rains in the Andean region of Peru.

\subsection{Data}

We used observational daily rainfall records from 19 stations located within MRB. The data was obtained from Geophysical Institute of Peru (IGP), National Service of Meteorology and Hydrology of Peru (SENAMHI), and ELECTROPERU (Table 1). The stations present missing data lower than $9 \%$ of the entire time series. 
Table 1. List of climatological stations used in this study.

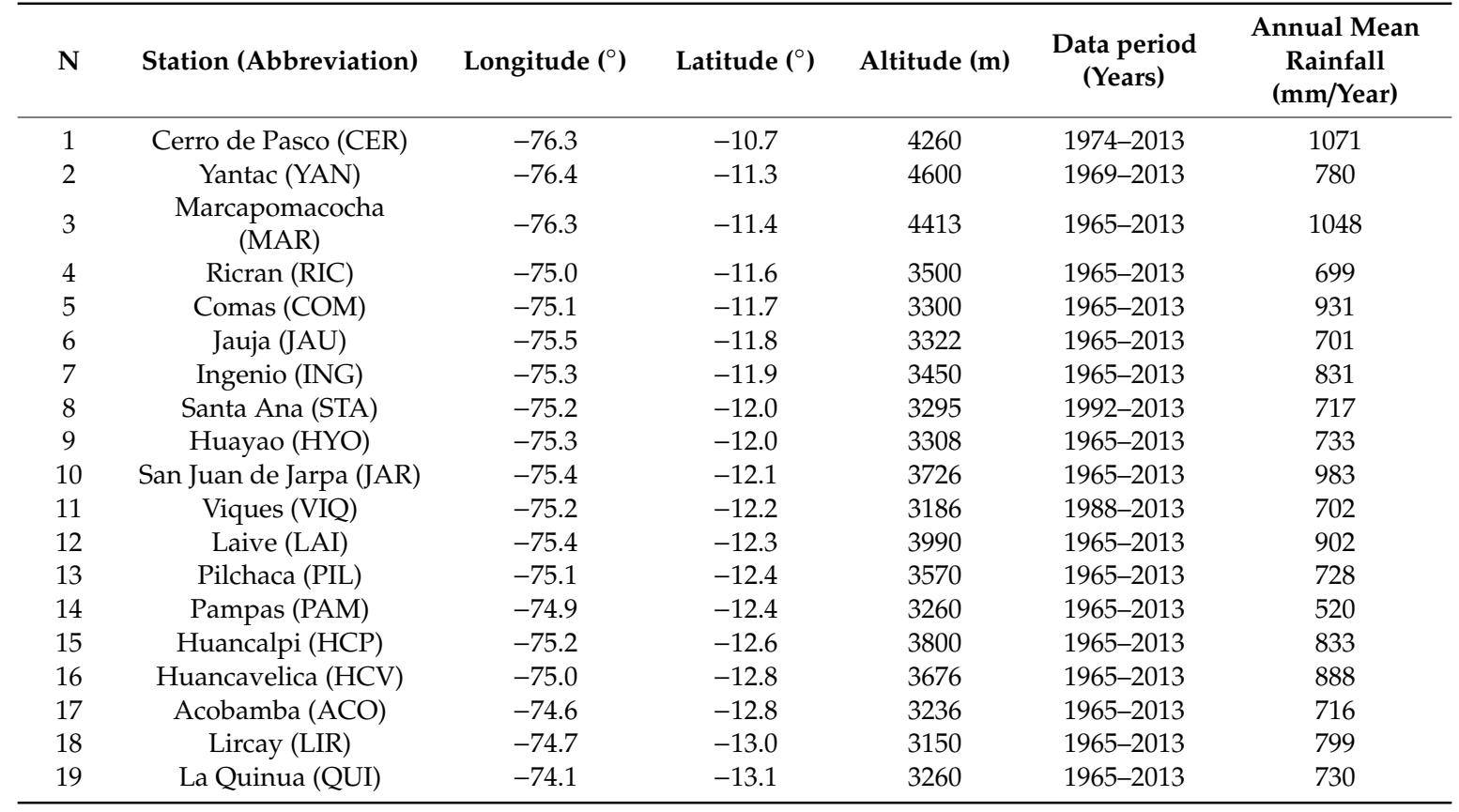

To describe the large-scale circulation associated with the onset, termination, and duration of the rainy season in MRB, we used daily zonal and meridional wind at $700 \mathrm{hPa}, 600 \mathrm{hPa}$, and $200 \mathrm{hPa}$ of ERA-Interim reanalysis from European Centre for Medium-Range Weather Forecasts (ECMWF) [39]. ERA-Interim has a resolution of $0.75^{\circ} \times 0.75^{\circ}$ and covers the $1979-2013$ period.

To characterize the climatological precipitation pattern of South America during the austral spring (SON) and austral summer (DJF), we used monthly gridded precipitation from the Global Precipitation Climatology Project (GPCP) [40]. GPCP dataset has a horizontal resolution of $2.5^{\circ} \times 2.5^{\circ}$ and covers the 1979-2013 period.

To study the change of convection over the central Peruvian Andes associated with the onset, termination, and duration of the rainy season over MRB, we used Outgoing Longwave Radiation (OLR) which is an useful index for the monitoring of the interannual variability of the rainy season and for providing an overall view of the distribution of the deep tropical convection over South America throughout the year [35,41]. We used the daily dataset of OLR at $2.5^{\circ} \times 2.5^{\circ}$ resolution from the National Centers for Atmospheric Research/National Oceanic and Atmospheric Administration (NCAR/NOAA) [42] for the 1974-2013 period. We also used the daily dataset of OLR at $1^{\circ} \times 1^{\circ}$ horizontal resolution from Earth System Science Interdisciplinary Center, University of Maryland (UMD/ESSIC) and NOAA Climate Data Record (CDR) Program for the 1979-2013 period [43].

\subsection{Methods}

To full out the missing values of the precipitation time series of the stations located within MRB, we used the Equation (1) that is described in [44].

$$
Y_{c i}=\left[\frac{Y r i * \bar{u} c j}{\bar{u} r j}\right]
$$

where $Y_{c i} i$ is the estimation of the missing data of the day $i$ of the candidate series, $Y$ ri is the data value of the reference series for the day $i, \bar{u} c j$ is the average of the candidate series for the period $j, \bar{u} r j$ is the average of the reference series for the period $j$. 
A PEN is defined as the accumulated precipitation of five consecutive days. A year starts from 1st July to 30th June of the following year, although February 29th was not considered in the calculation. Thus, in one year always contains 73 PENs. We also smooth the time series with three PENs (15 days).

The onset date and end date in each station are defined by a particular precipitation threshold (Table 2). These thresholds were computed through a frequency and intensity analysis of the precipitation PENs. The percentile 50 of the precipitation between July and December was used as the threshold for the identification of the onset of the rainy season. To identify the end of the rainy season, the threshold was the percentile 50 of the precipitation between January and June.

Table 2. Thresholds of the onset and end dates (in $\mathrm{mm}$ ) for each station located in MRB.

\begin{tabular}{cccc}
\hline $\mathbf{N}$ & Station (Abbreviation) & $\begin{array}{c}\text { Onset Threshold (mm) } \\
\text { [Percentile 50 (Jul-Dec) }\end{array}$ & $\begin{array}{c}\text { End Threshold (mm) } \\
\text { [Percentile 50 (Jan-Jun)] }\end{array}$ \\
\hline 1 & Cerro Pasco (CER) & 7.3 & 12 \\
2 & Marcapomacocha (MAR) & 5.9 & 12 \\
3 & Laive (LAI) & 4.2 & 9.5 \\
4 & San Juan de Jarpa (JAR) & 4.9 & 10.9 \\
5 & Yantac (YAN) & 3.7 & 8.3 \\
6 & Comas (COM) & 6.5 & 10.9 \\
7 & Ingenio (ING) & 3.5 & 8.5 \\
8 & Ricran (RIC) & 3.7 & 7.9 \\
9 & Jauja (JAU) & 2.6 & 7.1 \\
10 & Huayao (HYO) & 3.8 & 3.3 \\
11 & Santa Ana (STA) & 3.3 & 6.6 \\
12 & Viques (VIQ) & 1.8 & 5.1 \\
13 & Pilchaca (PIL) & 3.8 & 6.8 \\
14 & Pampas (PAM) & 2.1 & 4.6 \\
15 & Huancalpi (HCP) & 4.9 & 8.6 \\
16 & Huancavelica (HCV) & 4.5 & 9.7 \\
17 & Lircay (LIR) & 3.4 & 8.8 \\
18 & La Quinua (QUI) & 2.4 & 6.9 \\
19 & Acobamba (ACO) & 3.0 & 6.4 \\
\hline
\end{tabular}

To identify the onset and end dates of the rainy season over the MRB, we used the PENs criterion as was used by [10] and the moving average line as was used by [45]. In this study, we defined the onset dates of the rainy season when the first PEN of a set of six PENs between eight consecutive PENs exceed a precipitation threshold previously identified (Table 2), also the moving average line of three PENS must exceed the threshold determined. Analogously, the end date of the rainy season was determined as the previously PEN to the first PEN of a set of six PENs between eight successive PENs that not exceed a precipitation threshold previously determined (Table 2).

The duration of the rainy season is calculated by the Equation (2); where $\mathcal{D}$ represents the duration of the rainy season, $P f$ represents the number of the PEN in which the rainy season ends, and $P i$ represents the number of PEN in which the rains start.

$$
\mathcal{D}=[P f-P i]
$$

To estimate the onset and termination of the rainy season using OLR data, we consider $240 \mathrm{~W} / \mathrm{m}^{2}$ as the threshold, this threshold agrees with previous studies [10,46-48]. We defined the onset of the rainy season when six consecutive PENs are lower than $240 \mathrm{~W} / \mathrm{m}^{2}$ while the end date of the rainy season occurs when six consecutive PENs are higher than $240 \mathrm{~W} / \mathrm{m}^{2}$.

To check the statistical significance of the trends of the onset dates, end dates, and duration of the rainy season over MRB, we use two non-parametric significant tests (Mann-Kendall and Sen's slope estimator [49-51]). Sen's method is not affected by single data errors or outliers [52,53]. 
The Niño 4 index captures positive anomalies that exceed $0.5^{\circ} \mathrm{C}$ by a five consecutive month running average of SST, in the central equatorial Pacific, $5^{\circ} \mathrm{N}-5^{\circ} \mathrm{S}, 160^{\circ} \mathrm{E}-150^{\circ} \mathrm{W}$ [54].

The interpolation of the onset and end dates of the rains from a limited number of points was done through the spline method. Spline belongs to Radial Basis Functions (RBF) methods. These are exact interpolation techniques; it means that the calculated surface must pass through each input point. The spline method calculates surface using a mathematical function that transforms the surface curvature in a smoother surface. This method uses a mathematical function to fit the nearest input points passing through of them.

To study the existence of any preferential time band (years) of the onset day, end day, and duration of the rainy season over the central Peruvian Andes for the 1965-2012 period, we performed a wavelet analysis to precipitation and OLR time series. The mathematical details of the Wavelet coherence analysis are documented by [55-57].

\section{Results and Discussion}

\subsection{Determination of the Onset, Termination, and Duration of the Rainy Season over the MRB}

The spatial and temporal variability is higher in the onset dates (Figure 4a) than in the end dates (Figure $4 \mathrm{~b}$ ) of the rainy season in MRB. The spatial variability is probably due to the influence of a local pattern, such as the topography of the basin, while temporal variability is probably related to the influence of a global pattern, e.g., the transient systems to initiate and organize deep convection.
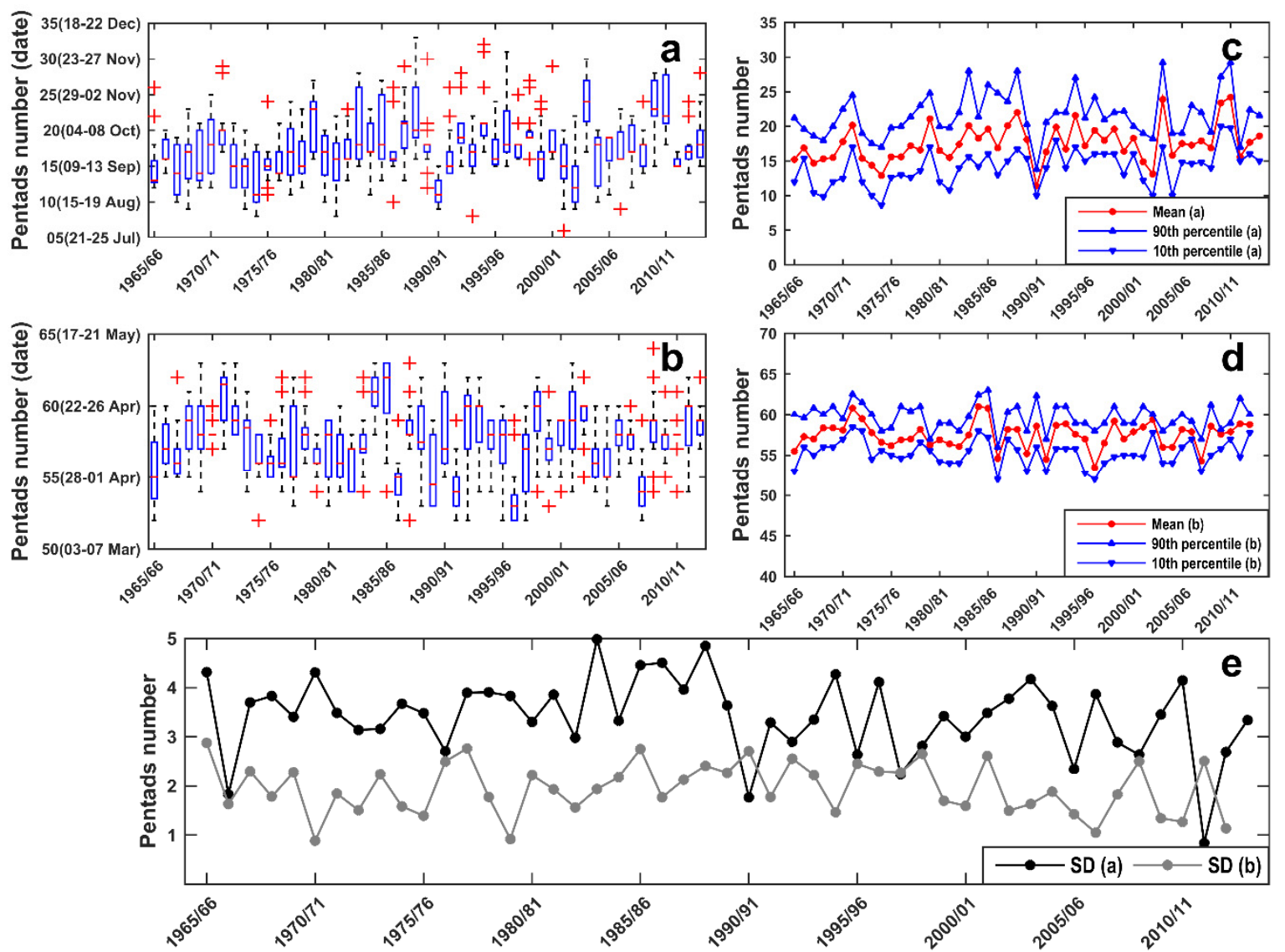

Figure 4. Boxplots of the (a) onset dates and (b) end dates of the rainy season. Mean, 90th and 10th percentile for (c) onset dates and (d) end dates of the rainy season. (e) Standard deviation (SD) for onset dates (a) and end dates (b) of the rainy season. Precipitation dataset (in PENs) was used for the 1965/66-2012/13 period in MRB. 
The mean onset date of the rainy season ranges between PEN 11 and 24 (Figure 4c) and the PEN 17 (19-23 September) represent the average onset date of the rainy season over MRB for the period 1965-2013, 10\% of the latest onset dates (90th percentile) are concentrated above PEN 29 (18-22 November), and 10\% of the earliest onset dates (10th percentile) are concentrated below PEN 9 (10-14 August). The mean end date of the rainy season ranges between PEN 53 and 61 (Figure 4d), and the PEN 57 (7-11 April) represents the average end date of the rainy season over MRB for the same period 1965-2013.

In MRB, the uncertainty in the determination of the onset dates is greater than in end dates of the rainy season because the standard deviation (SD) of the onset dates varies from \pm 1 to \pm 5 PEN, while the SD of the end dates varies from \pm 1 to \pm 3 PEN (Figure $4 \mathrm{e}$ ). Therefore, it is expected that onset date of the rainy season will be varying between PEN 11 and 24 ( \pm 1 to \pm 5 PEN), while the end date of the rainy season expected to vary between PEN 53 and 61 ( \pm 1 to $\pm 3 \mathrm{PEN})$. On average, the SD for the onset dates is $\pm 3.4 \mathrm{PEN}$ and $\pm 1.9 \mathrm{PEN}$ for the end dates of the rainy season in the MRB. Then, it is expected that the onset average of the rains is in the PEN 17 (19-23 September) \pm 3.4 PEN, likewise, the end average of the rains in the MRB is in the PEN 57 (7-11 April) \pm 1.9 PEN. These results show that the duration of the rainy season is modulated by the onset dates because the onset dates present higher variability than end dates. Additionally, we identified that the mean onset date of the rainy season over MRB occurs in the PEN 18 (24-28 September) for the 1979-2013 period.

The high variability of the onset days in the rainy season over MRB is consistent with the climatological features of the rainy season in other regions such as Amazon basin and eastern Africa. In Amazon basin e.g., the variability of the onset date (range of 25 PENs) in central Amazon is clearly largest compared to the end dates (range of 12 PENs) [10]. Also, there is considerably more variability in the onset dates than in the end dates over west-central Brazil during the period from July 1979 to June 1997 [33]. Conversely, Raia and Cavalcanti [13] found SD of 5 PENs in the onset and demise dates for some years, indicating a variation up to 25 days for Southeast regions of Amazonia. Concerning to eastern Africa, the interannual variability of the onset (SD of 14.5 days) is larger than that of the withdrawal (10.3 days) [58]. Exists quite a sizeable interannual variability central Senegal during 1950-1992, which is stronger for the onset (SD of 16 days) than for the end of the rains [59].

We made an analysis of the annual climatology of the precipitation over MRB using PENs of precipitation for the 1974-2013 period. The results confirm previous studies about the climatology of the precipitation over MRB [20,36]. The rainy season over MRB occurs between September of one year and April of the following year, the highest accumulations of precipitation occur from December to March of the next year (Figure 5a,b). The rainy season over MRB also coincides with the beginning and maturation phases of SAMS [26].

We repeat the analysis using the OLR dataset. Figure $5 \mathrm{~b}$ shows that PENs of observed precipitation and OLR present a significant negative correlation $(-0.98, p<0.01)$ for the period 1974-2013. These results evidence that OLR represents very well the seasonality of the rainfall in the MRB. Figure $5 \mathrm{~b}$ also shows that OLR reduces its intensity until $240 \mathrm{~W} / \mathrm{m}^{2}$ in the mid-September, the reduction progresses until it reaches its lowest value $\left(192 \mathrm{~W} / \mathrm{m}^{2}\right)$ in February, and OLR presents an increase of its intensity until the early May $\left(240 \mathrm{~W} / \mathrm{m}^{2}\right)$. The more significant convective activity occurs in February (e.g., lowest OLR anomalies), the month in which the accumulation of heavy rainfall is higher in the basin according to observed data of rain gauges (Figure $5 \mathrm{a}$ ).

Comparing the length of the rainy season in MRB respect to other regions of South America, such as Amazon basin, we found that the length of the rainy season over the Amazon basin is longer than the rainy season length over MRB. According to [10], in general, the average onset date in Amazon basin is the PEN centered on 25 September, and the ending date is the PEN centered on 2 June for 1979-1996 period (although each of the six regions of Brazilian Amazon basin have their particular features), while in MRB the onset date is the PEN centered on 25 September and the end date is the PEN centered on 9 April. 
In particular, we found that the MRB (49 PEN of rainy season length) has a slightly longer rainy season length than west-central Brazil (46 PEN of rainy season length). The onset dates extremes over MRB occur between PEN centered on 22 August and 26 October (range of 13 PEN), and the end dates extremes occurs between PEN centered on 20 March and 29 April (8 PEN). While the onset over west-central Brazil for the period occurs between the PENs centered on 15 September, and 14 November (12 PEN) and the end occurs between the PENs centered on 3 April and 3 May (6 PEN) [33]. This agrees with the results of the study by [13] that indicate SAMS duration determined with moisture flux index shows a shorter rain cycle than that found for the MRB. The climatological onset occurs at the end of October (PEN 60: 23-27 October) and the demise at the end of March (PEN 18: 27-31 March) during the period 1984-2004. While the onset dates in the MRB occur in the PEN centered on 24-28 September, and the mean end date of the rainy season occurs in the PEN centered on 7-11 April during the period 1979-2013.

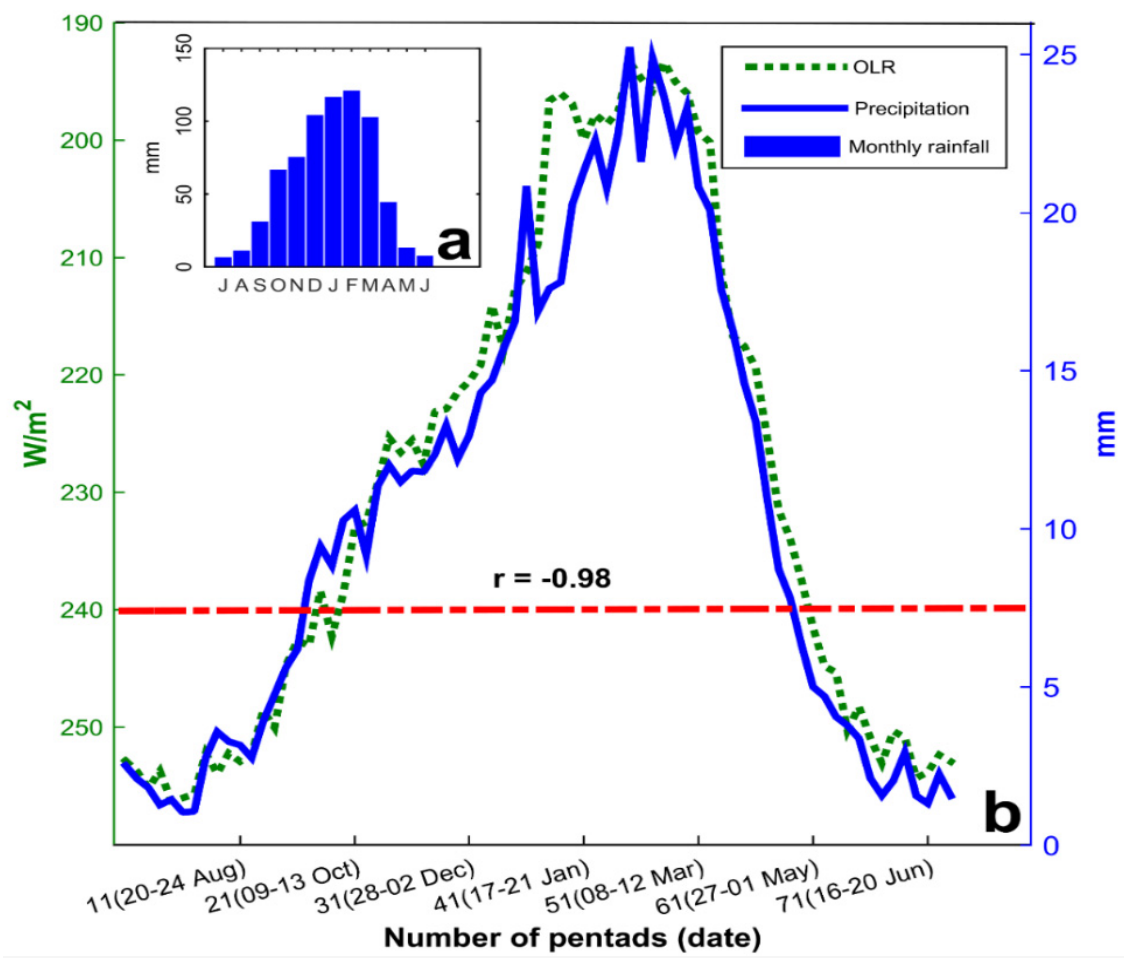

Figure 5. (a) Climatology of the monthly precipitation (mm) over MRB for the 1981-2010 period. (b) Precipitation in PENs based in rain gauges (solid blue line) and Outgoing Longwave Radiation (OLR) (green dotted line) for the 1974-2013 period. The OLR data set has a $2.5^{\circ}$ latitude-longitude resolution. Correlation between precipitation datasets is $-0.98(p<0.01)$. The OLR time series is plotted in reverse. The red dash-dotted line represents the OLR threshold $\left(240 \mathrm{~W} / \mathrm{m}^{2}\right)$.

\subsection{Spatial Distribution of the Onset Dates and End Dates of the Rainy Season over the MRB}

Figure 6a shows that the onset date of the rainy season begins in mid-September (14-18 September) in highland stations located over the northwestern MRB, progressing rapidly toward the center of the MRB (e.g., Mantaro valley), arriving there in the end of September (24-28 September). The propagation continues toward southwestern and southeastern MRB, arriving at the early October (29 September-3 October) and end of November (23-27 November), respectively. Figure 6b displays that the end date of the rainy season begins in the second week of April (07-11 April) over southern and central Mantaro valley, propagating rapidly in all directions toward the rest of $\mathrm{MRB}$, arriving to highland stations over the central-eastern MRB in the third week of April (17-21 April) and the central-western MRB at the end of April. 

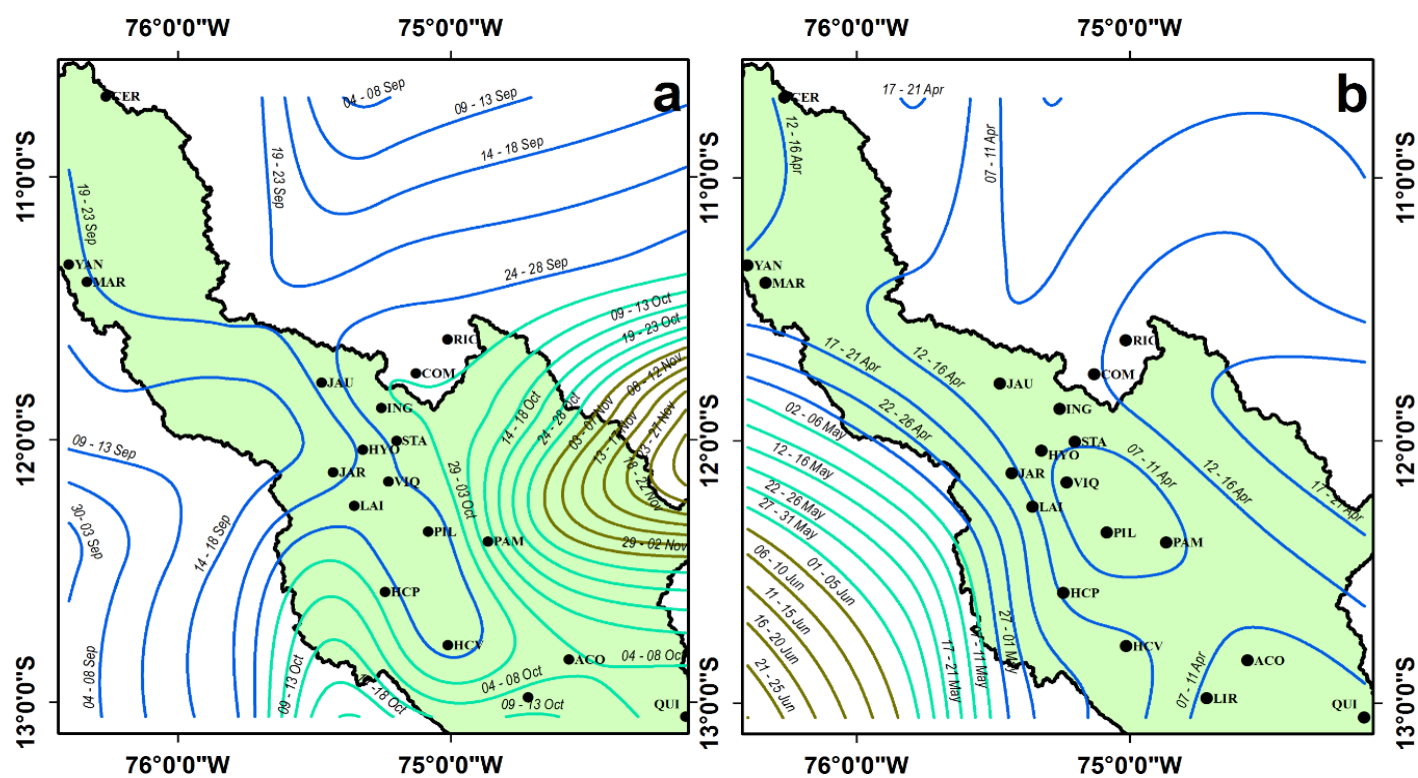

Figure 6. Spatial distribution of the isolines of (a) onset and (b) end dates of the rainy season over the MRB for the period 1965-2013. The blue line represents the onset dates in September and end dates in April. The light green line represents the onset dates in October and end dates in May. The dark green line represents the onset dates in November and the end dates in June.

An additional correlation analysis between local parameters (altitude, longitude, and latitude) and climatological features (onset date, end date, and duration) of the rainy season over MRB was computed to establish the influence of the local parameters on the spatial distribution of the climatological characteristics of the rainy season. Table 3 displays that altitude presents a negative correlation with onset dates $(-0.56)$ while the altitude presents a positive correlation with end dates and duration of the rainy season ( 0.69 and 0.72 , respectively). These results imply that stations located at low altitude feature late-onset dates and register early ending of the rainy season respect to the station located at high altitudes. Therefore, the rainy season in this part presents the shortest rainy season duration in MRB. Hence, all these results evidence that the local factor also has an essential role in the local distribution of the climatological characteristics of the rainy season over central Peruvian Andes.

Table 3. The correlation coefficient (r) among climatological characteristics of the rainy season (onset, end, and duration) over the MRB. This analysis was performed using all stations for the period 1965-2013. Only the coefficient correlation statistically significant at the $99 \%$ confidence level are shown in bold.

\begin{tabular}{cccc}
\hline Period 1965-2013 & Altitude & Longitude & Latitude \\
\hline Onset & -0.56 & -0.57 & +0.32 \\
End & $\mathbf{+ 0 . 6 9}$ & $\mathbf{+ 0 . 6 2}$ & -0.56 \\
Duration & $\mathbf{+ 0 . 7 2}$ & $\mathbf{+ 0 . 7 0}$ & -0.50 \\
\hline
\end{tabular}

\subsection{Interannual Variability of the Onset, End Dates, and Duration of the Rainy Season in the MRB}

We made an analysis of the interannual variability of the onset and end dates of the rainy season over MRB through the Principal Component Analysis (PCA), two PCA were computed using the onset and end dates of the rainy season for 19 stations of the MRB between 1965 and 2013. The spatial and temporal features associated with the first principal component (PC1) explain $55.2 \%$ of the variance of the rain onset dates (Figure 7a). The PC1 is useful to identify the regional variations of the rainfall onset dates in the MRB, as did other authors [40]. Figure 7a also displays that all loadings of the PC1 are positive with values higher than 0.352 over valley $M R B$ and eastern part of central MRB, which are considered a significant and robust signal of a positive correlation between these stations. This first 
mode of variability indicates that the positive values of the components are associated with late-onset and negative values to early onset of the rains; thus, between 1965 and 2013 the earliest onset was presented in 1969, while the later-onset was in 2009 (Figure 7a). Figure 7a shows that 18 years of all time series present late-onset while 29 years of total correspond to early-onset. The second principal component (PC2) explains $12.5 \%$ of the variability of the onset dates in MRB and represents the stations located in high regions of the north and center of the MRB. The third principal component (PC3) with $8 \%$ of the explained and the fourth principal component (PC4) with 7\% of explained variability. The last three principal components (PC2, PC3, and PC4) will not be considered in the remaining analysis. Figure 7a also shows the existence of periodicity of 4-5 years in the onset day time series. This latter is ratified by an additional wavelet analysis that displays a band of 4-5 years between 1983 and 2012 for the onset time series of PC1 (Figure 8a).

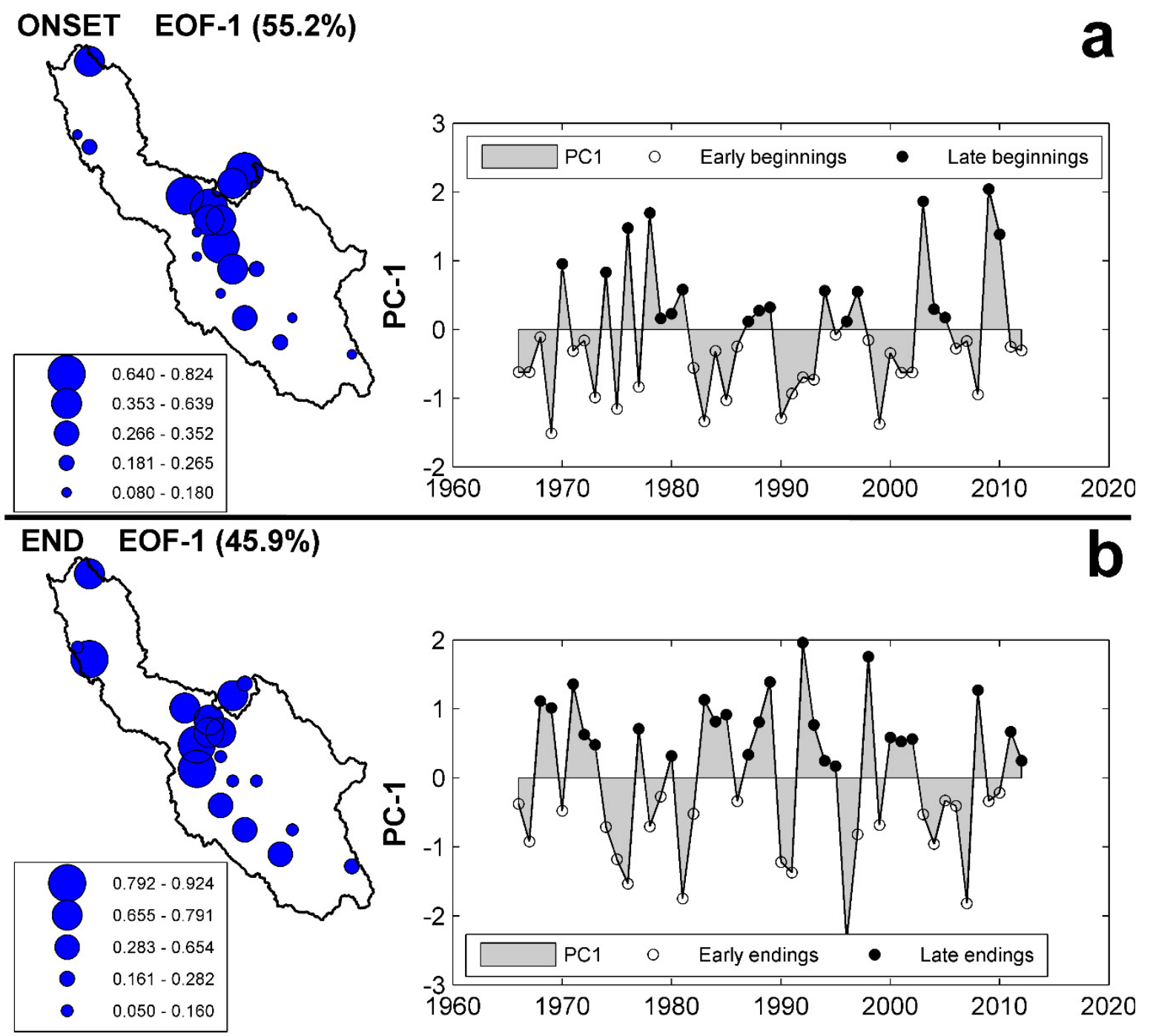

Figure 7. Spatial and temporal variation of the first component for (a) rainfall onset date and (b) rainfall end date of the rainy season. White dotes represent early onset and early end dates. Black dotes represents late begin and late end dates. Analysis for the 1966-2013 period. 
a) Wavelet(ANOM. ONSET (PRE-Pentad))

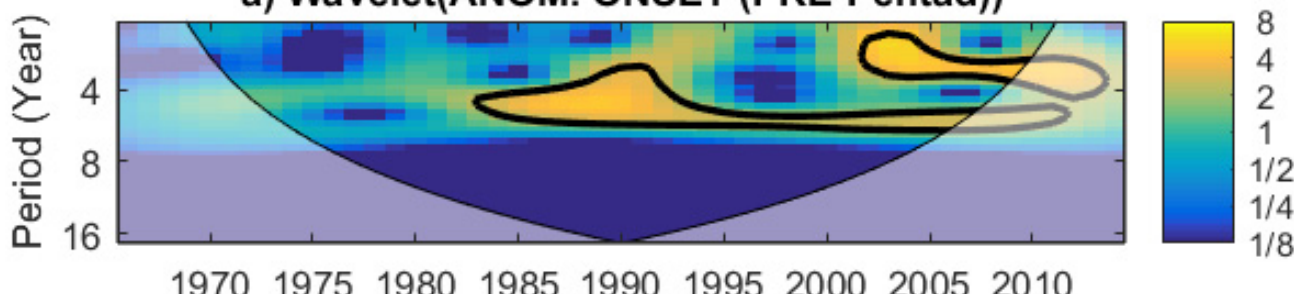

197019751980198519901995200020052010

b) Wavelet(ANOM. END (PRE-Pentad))

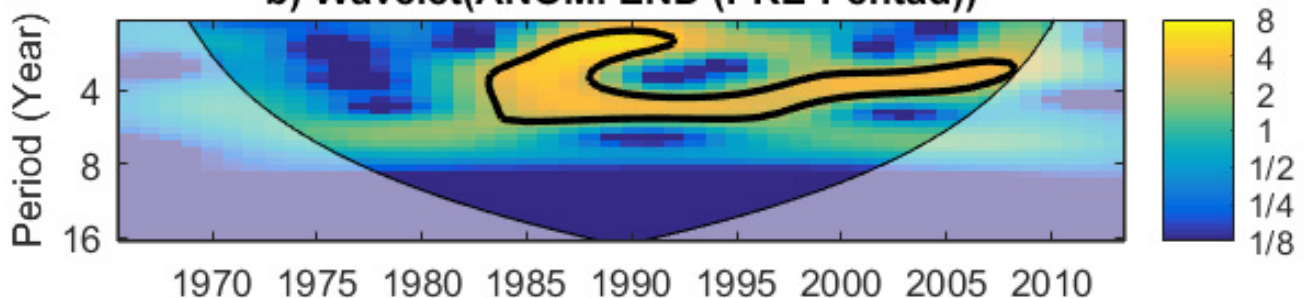

c) Wavelet(ANOM. DURATION (PRE-Pentad))

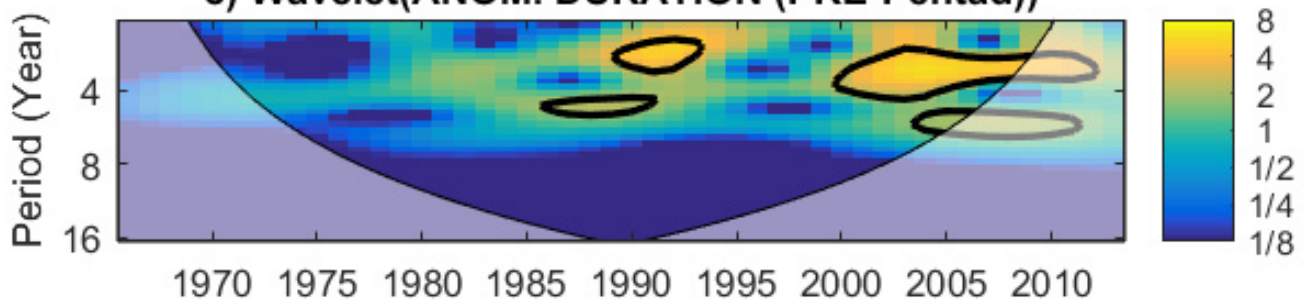

Figure 8. Wavelet analysis for time series of (a) onset, (b) end, and (c) duration of the rainy season over MRB for the 1963-2013 period. The black line is the 5\% significance level using the red noise model, and the thin black line indicates the zone of influence.

The spatial and temporal features associated with the PC1 explain $45.9 \%$ of the variance of the rain end dates (Figure $7 \mathrm{~b}$ ). Figure $7 \mathrm{~b}$ also shows that all stations located within MRB present positive loading of PC1, the highest values (>0.654) prevail over the valley MRB and highland regions in the central and north part of the MRB. This first mode of variability indicates that the positive values of the components are associated with late endings and negative values to early endings of the rains. Moreover, Figure $7 \mathrm{~b}$ shows that 24 years of all time series present late ending while 23 years of all time series present an early ending. The earliest ending was presented in 1996, while the later ending was in 1992 (Figure 7b). The other components explain in a smaller percentage the variability (PC2, PC3, and PC4 represent $11.7 \%, 9.93 \%$, and $7.58 \%$ of explained variability, respectively). Moreover, Figure $7 \mathrm{~b}$ portraits the existence of small bands of a 3, 4, and 5 years of the end time series of PC1. This latter result is consistent with the existence of a significant band of five years between 1983 and 1998, while there is a band of 3-4 years between 2000 and 2006 (Figure 8b). Conversely, the duration of the rainy period does not present a preferential band (Figure 8c).

Climatologically, Figure 7 a displays that $35.7 \%, 28.6 \%$, and $35.7 \%$ of years with negative anomalies of the onset dates between 1965 and 2013 occur during Neutral, El Niño, and La Niña years, respectively. Figure $7 \mathrm{~b}$ also displays that $33.3 \%, 29.2 \%$, and $37.5 \%$ of years with positive anomalies of end dates are consistent with Neutral, El Niño, and La Niña years, respectively. These results suggest that La Niña favors early onset and late end of the rainy season. Moreover, Figure 7 a portraits that $41.2 \%, 35.3 \%$, and $23.5 \%$ of all years with positive anomalies of onset dates occur during Neutral, El Niño and La Niña, respectively. Figure $7 \mathrm{~b}$ also displays that $30 \%, 40 \%$, and $30 \%$ of years with negative anomalies of end dates occur during Neutral, El Niño, and La Niña, respectively. These last results suggest that El Niño favors late-onset and early end of the rainy season in the MRB, El Niño is associated with the occurrence of the early end of the rainy season due to it inhibits austral summer precipitation over central Peruvian Andes [4]. 
An additional correlation analysis was made to establish the relationship between the onset date, end date and duration of the rainy season over MRB for the 1965-2013 period. Table 4 shows that the duration and onset dates have a negative correlation that varies between -0.95 and $-0.76(p<0.01)$. It agrees with the existence of a delay in the onset dates that reduces the duration of the rainy season. Table 4 also shows that end dates and the duration have an insignificant correlation. It suggests that the duration of the rainy season is not influenced completely by the termination of the rainy season while the opposite occurs with the delay in the onset dates. Hence, the results show that onset dates and end dates present a non-significant correlation that varies between -0.3 and 0.3 . This later means that early-onset date does not induce necessary an early end date and vice-versa.

Table 4. Range of the correlation coefficient (r) among climatological characteristics of the rainy season (onset, end, duration, and total amount) over the MRB. This analysis was performed using all stations for the period 1965-2013. Only the coefficient correlation statistically significant at the $99 \%$ confidence level are shown in bold.

\begin{tabular}{cccc}
\hline Period 1965-2013 & End & Duration & Total Amount \\
\hline Onset & $-0.3<\mathrm{r}<+0.3$ & $-\mathbf{0 . 9 5}<\mathrm{r}<-\mathbf{0 . 7 6}$ & $-0.5<\mathrm{r}<+0.5$ \\
End & & $+0.23<\mathrm{r}<+0.7$ & $-0.6<\mathrm{r}<+0.6$ \\
Duration & & & $\mathrm{r}<+0.6$ \\
\hline
\end{tabular}

\subsection{Trend of the Onset Dates, End Dates and Duration of the Rainy Season over MRB}

There is a predominance of positive trends of the onset dates over the northeastern, central and southern part of MRB (12 out of 19 stations) for the period 1965-2013 (Figure 9a). However, Figure 9a also shows a negative trend over the southwestern part and the eastern boundary of the central part of MRB. While the non-significant trend partially prevails over the central and northwestern MRB. These results show that negative and insignificant trends prevail in the highland stations ( $>4500$ masl.). However, the end dates of the rainy season do not present a significative tendency, except for two stations that show positive trends (Figure 9b). Analogously, the duration of the rainy season over MRB presents a negative trend in the same stations as in Figure 9a, except for five highland stations (Figure 9c). It evidences a reduction of the duration of the rainy season over MRB.

We repeat the same analysis through PENs of precipitation from rainfall-gauge stations and OLR (Figures 10 and 11). Figure 10a evidences a delay of 3 days/decade in the onset dates of the rainy season. The end dates present a positive trend of 0.3 days/decade, although is no statistically significant (Figure 10b). The duration of the rainy season shows a significant negative trend $(\sim 3$ days/decade, $p<0.1$ ) (Figure 10c). It evidences a reduction of the duration of the rainy season over the MRB in the last four decades. This reduction agrees with the reduction from 40 PENs (200 days) in the early decades to 35 PENs (175 days) in the last decades. Moreover, the shortening of the duration of the rainy season over MRB agrees with the documented in [9], who used daily precipitation concentration of stations located within the MRB.

We compare the onset, end and duration trends of the rainy season for the same period 1979/80-2012/13 at different OLR resolutions ( $2.5^{\circ}$ and $1^{\circ}$ latitude-longitude), see Figure 11a-c. At $2.5^{\circ}$ OLR resolution, the onset dates increase significantly in 10 days/decade (Figure 11a). The end of the rainy season shows a significant decrease of -5.9 days/decade (Figure 11b). The duration of the rainy season shows a significant decrease of -13.6 days/decade (Figure 11c). Concerning to OLR dataset at $1^{\circ}$ horizontal resolution, the rainy season onset shows a slight delay of 0.9 days/decade (Figure 11a). The end of the rains decreases in -1.65 day/decade (Figure 11b), and the duration shows a slight tendency to shorten in 2.4 days/decade (Figure 11c). However, these trends are not significant.

For a more extended period 1974/75-2012/13 at 2.5 OLR resolution (Figure $11 \mathrm{~d}-\mathrm{f}$ ), there is a delay in the rainfall onset of 3.7 days/decade (Figure 11d). The end dates decrease in 4.4 days/decade (Figure 11e). The duration of the rainy period shortens in 7.15 days/decade (Figure 11f). The end and duration trends show significance at $90 \%$ of the confidence level. Thus, we confirm that the OLR 
dataset only gives us a rough approximation as to the onset and end dates of rainy seasons, as [10,47] also indicated. All these results evidence a delay of the onset date, also the duration of the rainy season tends to shorten.

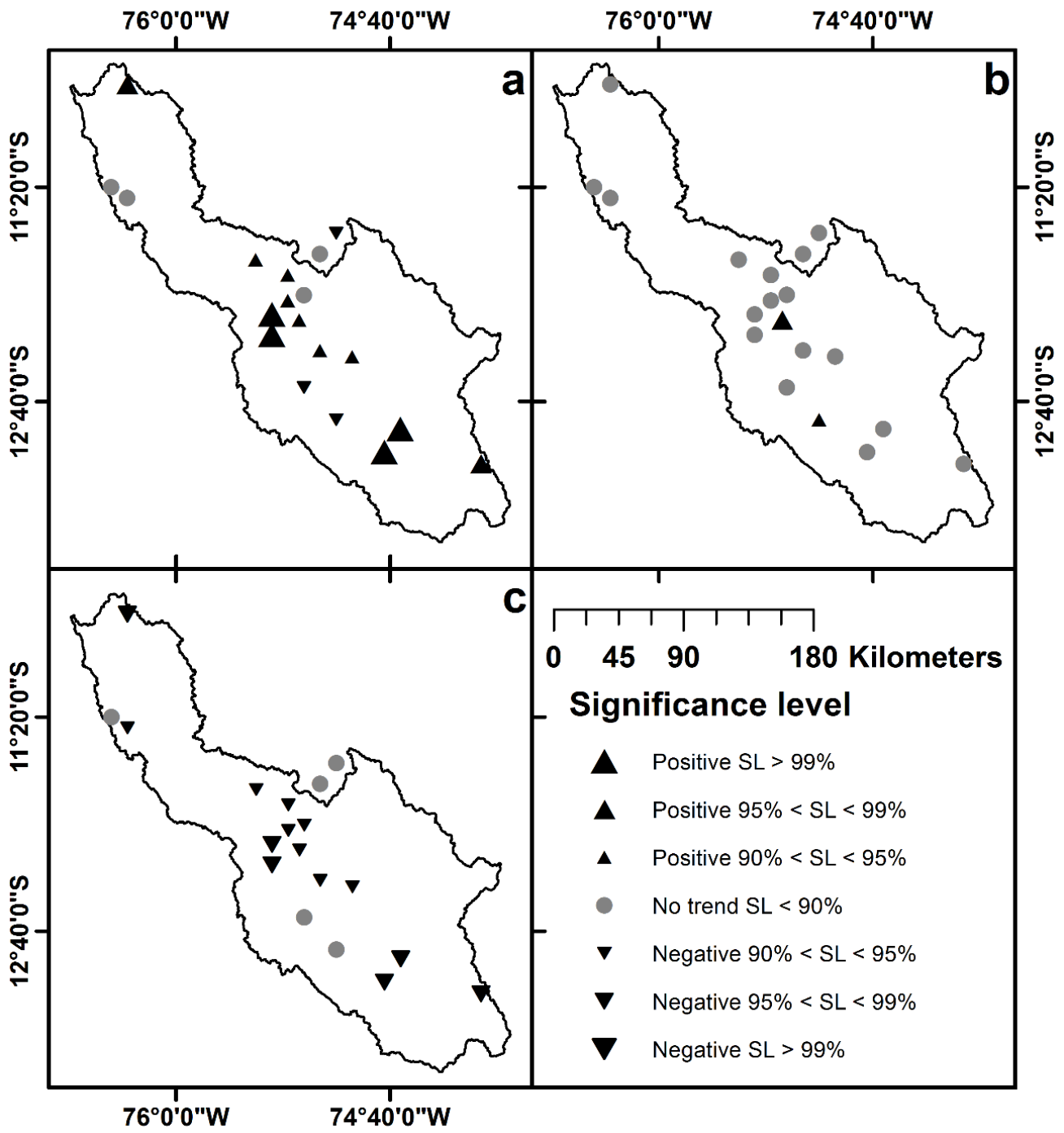

Figure 9. Spatial distribution of the annual trend of the precipitation over the MRB: (a) Onset dates, (b) end dates, (c) duration of the rainy season. Positive trends are represented by up black triangle, negatives correlations are represented by black down triangles, and correlation lower than $90 \%$ are represented by gray dots.

Comparing with the results of the study by [32] who use the LISAM index for Brazil, they found an increase in the length of the rainy season, while MRB presents a shortening of the rainy season. Carvalho et al. [32] indicate that onset dates have a significant change in the early 1970s and tend now to occur earlier than PEN 60 (23-27 October). Likewise, progressive increases in end dates were observed from 1948 to the late 1970s, in general, occurred later than PEN 23 (21-25 April) after the mid-to-late 1970s. Consequently, SAMS duration determined with LISAM shows an increase in the length of the rainy season from 1948 to 2008. The mean duration was 34 PENs ( 170 days) during 1948-1972 and 39 PENs (195 days) in 1972-1982 [32]. They show that these changes are associated with an increment of the moisture flux over South America after 1971-72. The opposite occurs in MRB, the onset dates increase progressively. The onset dates until the 2000s become earlier than 14-18 October, and in the last decade (2003-2013) we find a later onset between 24-28 October. While, the end dates not show any tend, on average, the end date occurs between 7-11 April, some PENs before the SAMS 
end. On average, the duration of rains is 40 PENs (200 days), but the duration of the rainy season shows a tendency to shorten.

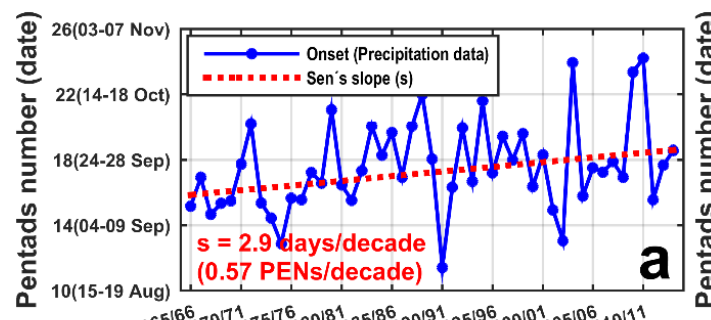

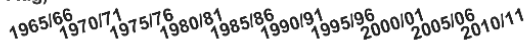

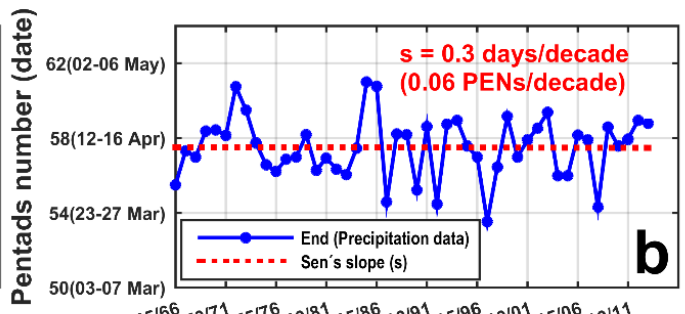

1965166901711975176801819851869019195519600101005106010111

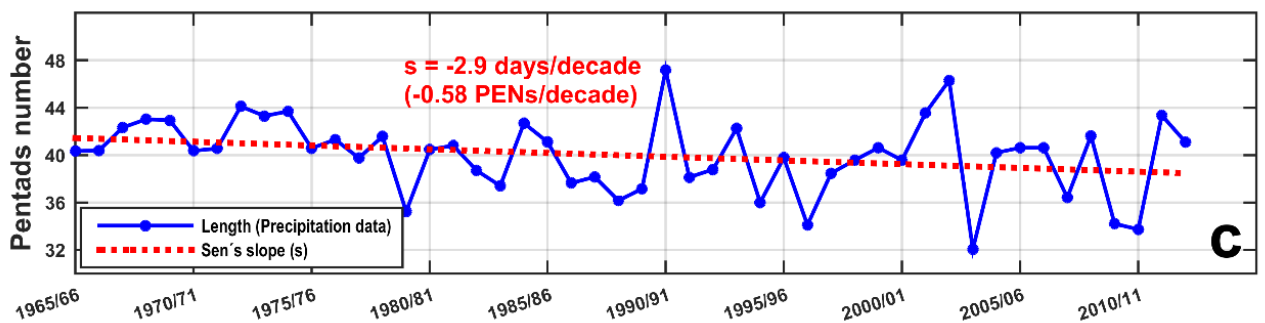

Figure 10. Timeseries of the number of PENs (blue line) and decadal trend (red dots line) for (a) onset, (b) end, and (c) duration of the rainy season over the MRB for the period 1965-2013. Only the onset trend is statistically significant at $95 \%$ confidence level, while the trend of the duration of the rainy season is statistically significant at a $90 \%$ confidence level.
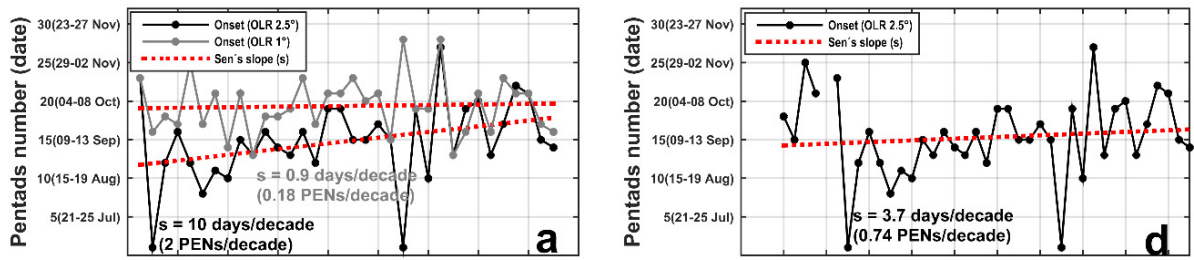

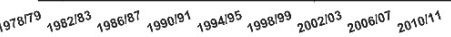
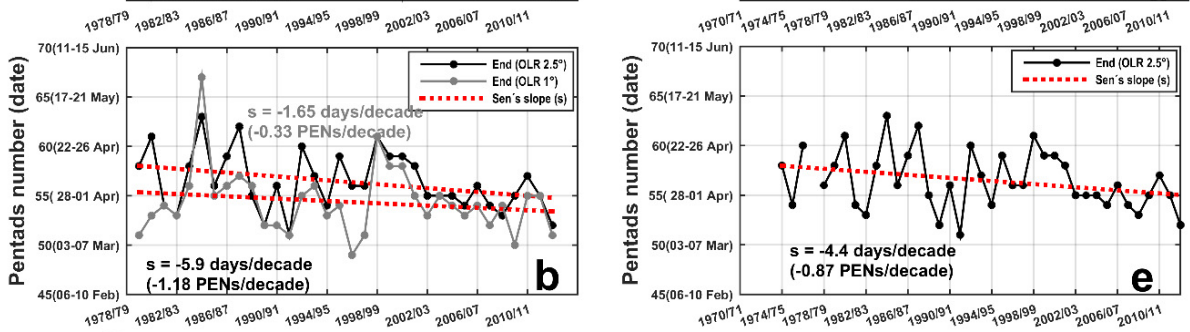

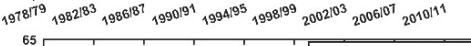

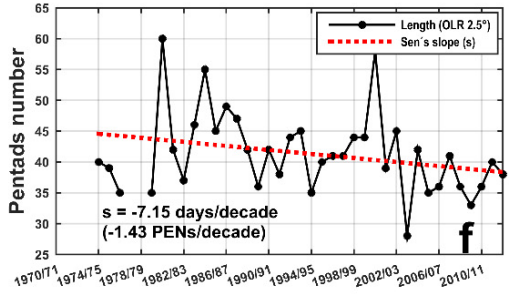

Figure 11. Timeseries of the number of PENs (black and grey line) and trend (red dots line) for the onset $(\mathbf{a}, \mathbf{d})$, end $(\mathbf{b}, \mathbf{e})$, and duration $(\mathbf{c}, \mathbf{f})$ of the rainy season over the MRB computed of OLR dataset for 1979/80-2012/13 (a-c) and 1974/75-2012/13 (d-f) period. At 2.5 OLR latitude-longitude resolution (black line) and $1^{\circ}$ OLR latitude-longitude resolution (grey line). For the period 1979/80-2012/13, the onset, end and duration trend with $2.5^{\circ}$ OLR resolution are statistically significant at $95 \%$ confidence level while the onset, end and duration trend with $1^{\circ}$ OLR resolutions are not significant. For the period 1974/75-2012/13, the end and duration trend of the rainy season is statistically significant at $90 \%$ confidence level while the onset trend of the rainy season is not significant. Missing values of OLR data $(17 / 03 / 1978-31 / 12 / 978)$. 
According to these results, the MRB has suffered a reduction in the duration of the rainy season. The shortness of the duration of the rainy season affects the water supply to several sectors such as agriculture. Indeed, many crops will be affected by water scarcity during some sensitivity phases of their vegetative cycle. Hence, we must select crops that have a short cycle as an adaptation measure. These results also confirm clearly the farmer's perception of the delaying of the onset date.

\subsection{Large-Scale Atmospheric Circulation over South America Associated with Early and Late-Onset Dates of the Rainy Season over MRB}

The evolution of the regional convection and horizontal wind over South America during the rainy season onset in MRB is described in the supplementary material.

The difference of the atmospheric circulation patterns e.g., composites of OLR $\left(\mathrm{W} / \mathrm{m}^{2}\right)$ and wind $(\mathrm{m} / \mathrm{s})$ at $600 \mathrm{hPa}$, among four consecutive PENs after $(\mathrm{PEN}+1,+2,+3$, and +4) minus four consecutive PENs previous (PEN $-4,-3,-2$, and -1 ) to the onset date (PEN 0 ) has been analyzed for early and late-onset date of the rainy season in the MRB are shown in Figure 12. Figure 12a shows that negative OLR differences and northeasterly wind differences over the MRB are characteristic for early-onset dates. The negative OLR differences prevail between $13^{\circ} \mathrm{S}$ and $4^{\circ} \mathrm{N}$ although their lowest values are recorded over northwestern Tropical Andes, although it weakens progressively to the east until it reaches $50^{\circ} \mathrm{W}$. These circulation differences highlight the southward propagation of the convective region of the SAMS during the early onset date of the rainy season over MRB. Figure 12a also shows negative OLR differences over the equatorial Atlantic Ocean. It suggests that the convection activity over the equatorial Atlantic Ocean enhances the humidity influx from the Atlantic Ocean to central Peruvian Andes.

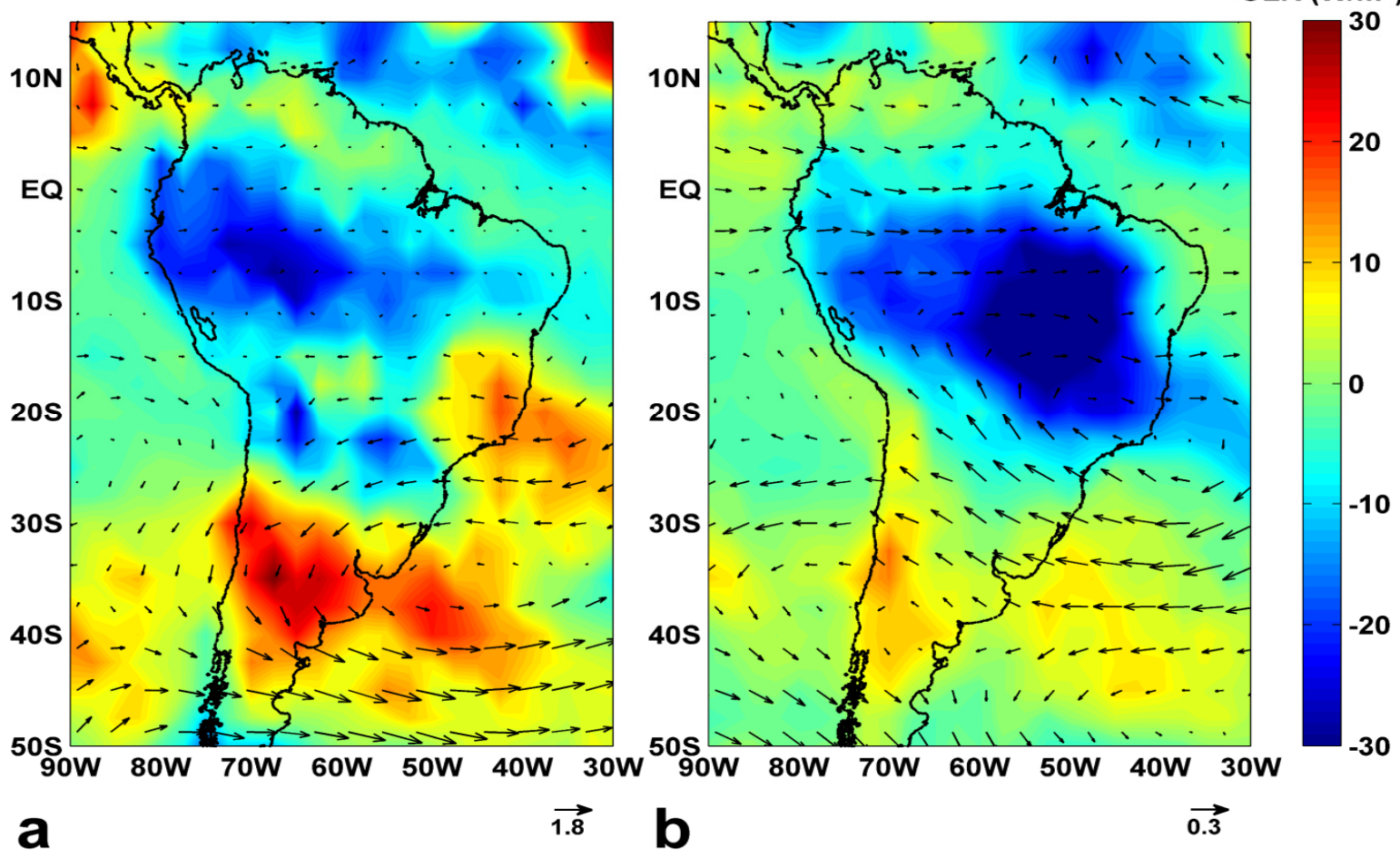

Figure 12. Composites of $600 \mathrm{hPa}$ winds $(\mathrm{m} / \mathrm{s})$ and OLR $\left(\mathrm{W} / \mathrm{m}^{2}\right)$ for the difference of four PENs after minus four previous PENs of the onset of the rainy season in MRB. (a) Early beginnings years and (b) late beginnings years of the rain season. Analysis based on ERA-Interim reanalysis. The OLR data set has a $2.5^{\circ}$ latitude-longitude resolution.

According to late-onset dates, Figure $12 \mathrm{~b}$ shows that negative OLR differences and southwesterly wind differences at $600 \mathrm{hPa}$ over the MRB. The negative OLR differences prevail between $25^{\circ} \mathrm{S}$ and $4^{\circ} \mathrm{S}$ 
although their lowest values are recorded over central, northeastern Brazil, it weakens progressively to the west until reaches the central Peruvian Andes $\left(12^{\circ} \mathrm{S}, 82^{\circ} \mathrm{W}\right)$. Figure $12 \mathrm{~b}$ also shows an oblique band of negative OLR differences from eastern Brazil into the Southern Atlantic Ocean while positive OLR differences are observed over the equatorial Atlantic Ocean. These circulation differences evidence a northeastern displacement of the climatological position of the SACZ [60], and a reduction of the convective activity over the equatorial Atlantic Ocean. These latter features imply a weakening of humidity influx toward central Peruvian Andes by a reduction of the amount of humidity. All these circulation differences show that late-onset date of the rainy season over MRB and enhanced precipitation over the central and eastern parts of northeastern Brazil are associated with the eastward shift of the convective region of SAMS due to northward displacement of the SACZ.

\section{Conclusions}

The seasonality changes of the rainy season over MRB, which is located in the central Peruvian Andes, were analyzed for 1965-2013 period. Our findings show that rainy seasons are induced during the southward propagation of convective regions from the Caribbean region toward southern and central Amazon basin between end-September (19-23 September, onset date) and early-April (7-11 April, end date), where the rainiest month is February. The variability of the onset dates is greater $( \pm 1$ to \pm 5 PEN) than end dates ( \pm 1 to \pm 3 PEN) of the rainy season.

The spatial distribution of the onset date of the rainy season indicates that this beginning in the mid-September (14-18 September) in highland stations located over the northwestern MRB, progressing rapidly toward the center of the MRB (e.g., Mantaro valley), arriving there at the end of September (24-28 September), the propagation continues toward southern western and southeastern MRB, arriving at the early October (29 September-3 October) and end of November (23-27 November), respectively. Moreover, the end date of the rainy season begins in the second week of April (7-11 April) over southern and central Mantaro valley, propagating slowly in all directions toward the rest of MRB arriving to highland stations over the central-western MRB at the end of April while arriving over the central-eastern MRB in the third week of April (17-21 April).

On interannual timescales, onset dates present periodicity of 4-5 years between 1983 and 2012 while the end dates and duration of the rainy season do not present a periodicity band. Furthermore, the changes of the SST indices over the Pacific modulates the climatological features (e.g., onset date, end date, and duration) of the rainy season over MRB. Our results suggest that La Niña favors early onset and late end of the rainy season, while El Niño favors late-onset and early end of the rainy season in the MRB.

The tendency analysis with precipitation data evidences a reduction of the rainy season length ( $\sim 3$ days/decade) over MRB for the period 1965-2013. It is confirmed by the analysis with the OLR dataset at different resolutions $\left(2.5^{\circ}\right.$ and $1^{\circ}$ latitude-longitude) for the period 1979/80-2012/13 and 1974/75-2012/13, where we show the existence of a delay of the onset date as well as shortening of the rainy season.

Dynamically, the onset of the rainy season over MRB is induced by the propagation of the convective region from the Caribbean region to the central Amazon basin. The early and delay onset of rainy season over MRB present quite different large-scale pattern over SA. For example, the early onset date of the rainy season over MRB is characterized by $600 \mathrm{hPa}$ northeasterly wind anomalies and low OLR $\left(<240 \mathrm{~W} / \mathrm{m}^{2}\right)$, which even extends a vast region than just MRB itself. These features are caused by the southward shift of the SACZ that induces the southernmost propagation of the convective region of SAMS from the Caribbean region to the southernmost Amazon basin. Conversely, the delay of the onset of the rainy season presents $600 \mathrm{hPa}$ northeasterly wind anomalies and OLR lower than $240 \mathrm{~W} / \mathrm{m}^{2}$ in MRB (weaker than in early-onset episodes), which even present in whole Tropical Andes. This delay is caused by the northward position of the SACZ and convection over the equatorial Atlantic Ocean that induce an eastward shift of the convective region of the SAMS toward central-eastern Brazil. 
Ultimately, this study will contribute to a better understanding of the causes of interannual variability of onset and end rainfall dates in the MRB. The results can use to sensitizations of people on how climate change will be impacting the rainfall seasonality and how they must adapt. According to this study, new studies could be carried out on forecasts of the date of onset of rain in the Peruvian Andes. The development of a monitoring and prediction system could help to plan better several economic activities, such as agriculture. Precise forecasting could prevent and mitigate the damage in local agriculture.

Supplementary Materials: The following are available online at http://www.mdpi.com/2225-1154/8/2/23/s1, Figure S1 [26,61]: Superposed epoch analysis for OLR $(\mathrm{W} / \mathrm{m} 2)$ and $600 \mathrm{hPa}$ winds $(\mathrm{m} / \mathrm{s})$ for the period prior (4 PENs before) and immediately following (4 PENs after) of the rainy season onset (PEN 0: 24-28 September) over the MRB for the 1979-2013 period. Analysis based on ERA-Interim reanalysis. The OLR data set has a $2.5^{\circ}$ latitude-longitude resolution, Figure S2: As in Figure S1, but for $200 \mathrm{hPa}$, Figure S3: Composite of $600 \mathrm{hPa}$ wind $(\mathrm{m} / \mathrm{s})$ and OLR (W/m2) over South America for (a) four previous PENs to onset of the rainy season (PEN 14-17), (b) four PENs after the onset of the rainy season (PEN 19-22). Analysis based on the 1979-2013 period. ERA-Interim reanalysis was used in this analysis. The OLR data set has a $2.5^{\circ}$ latitude-longitude resolution, Figure S4: As in Figure S3, but at $200 \mathrm{hPa}$.

Author Contributions: L.G. conceptualization, obtained and analyzed the datasets, created the figures, and analyzed the results, writing - review and editing; Y.S. participated in the conception of the study; Y.S. and R.Z. reviewed the methodology and the statistical analysis of the data and supervision; J.S. assisted with some data processing, analysis, and editing of the manuscript. All authors contributed to the discussion of the results, wrote, and reviewed the manuscript. All authors have read and agreed to the published version of the manuscript.

Funding: This research was funded by FONDECYT, CONCYTEC, Peru (grants 010-2017-FONDECYT).

Acknowledgments: Present study comes under the project "MAGNET-IGP: Strengthening the research line in physics and microphysics of the atmosphere (Agreement $\mathrm{N}^{\mathrm{o}}$ 010-2017-FONDECYT)". The authors would like to thank the Geophysical Institute of Peru (IGP), National Service of Meteorology and Hydrology of Peru (SENAMHI), and ELECTRO-PERU for providing observed precipitation data; European Centre for Medium-Range Weather Forecasts (ECMWF) for providing ERA-Interim reanalysis dataset; Global Precipitation Climatology Project (GPCP) for providing monthly precipitation dataset; National Centers for Atmospheric Research/National Oceanic and Atmospheric Administration (NCAR/NOAA) for providing daily dataset of OLR at $2.5^{\circ} \times 2.5^{\circ}$ resolution; Earth System Science Interdisciplinary Center, University of Maryland (UMD/ESSIC) and NOAA Climate Data Record (CDR) Program for providing daily dataset of OLR at $1^{\circ} \times 1^{\circ}$ resolution. We also would like to thank the comment and constructive suggestions of the IGP team.

Conflicts of Interest: The authors declare no conflict of interest.

\section{References}

1. Pascale, S.; Lucarini, V.; Feng, X.; Porporato, A.; Shabeh Hasson, U. Analysis of rainfall seasonality from observations and climate models. Clim. Dyn. 2015, 44, 3281-3301. [CrossRef]

2. Feng, X.; Porporato, A.; Rodriguez-Iturbe, I. Changes in rainfall seasonality in the tropics. Nat. Clim. Chang. 2013, 3, 811-815. [CrossRef]

3. Saeed, F.; Bethke, I.; Fischer, E.; Legutke, S.; Shiogama, H.; Stone, D.A.; Schleussner, C.-F. Robust changes in tropical rainy season length at $1.5^{\circ} \mathrm{C}$ and $2{ }^{\circ} \mathrm{C}$. Environ. Res. Lett. 2018, 13, 064024. [CrossRef]

4. Silva, Y.; Takahashi, K.; Chavez, R. Dry and wet rainy seasons in the Mantaro river basin (Central Peruvian Andes). Adv. Geosci. 2008, 14, 261-264. [CrossRef]

5. Silva, Y.; Trasmonte, G.; Giráldez, L. Variabilidad de las Precipitaciones en el valle del río Mantaro. In Memoria del Subproyecto "Pronóstico Estacional de Lluvias y Temperaturas en la Cuenca del río Mantaro Para su Aplicación en la Agricultura"; Silva, Y., Ed.; Fondo Editorial CONAM-Instituto Geofisico del Perú: Lima, Peru, 2010; pp. 54-58. ISBN 978-612-45795-3-0.

6. Autoridad Nacional del Agua. Evaluación de Recursos Hídricos Superficiales en la Cuenca del río Mantaro; Mantaro, A.L.A., Ed.; Autoridad Nacional del Agua: Lima, Perú, 2010.

7. Zubieta, R.; Lagos, P. Glaciares y Cambio Climático en la Cuenca del Río Mantaro. In Cambio Climático en la Cuenca del Río Mantaro.; Martínez, A.G., Pérez, S., Eds.; Instituto Geofísico del Perú: Lima, Perú, 2010; pp. 59-67.

8. López-Moreno, J.I.; Fontaneda, S.; Bazo, J.; Revuelto, J.; Azorin-Molina, C.; Valero-Garcés, B.; Morán-Tejeda, E.; Vicente-Serrano, S.M.; Zubieta, R.; Alejo-Cochachín, J. Recent glacier retreat and climate trends in Cordillera Huaytapallana, Peru. Glob. Planet. Chang. 2014,112, 1-11. 
9. Zubieta, R.; Saavedra, M.; Silva, Y.; Giráldez, L. Spatial analysis and temporal trends of daily precipitation concentration in the Mantaro River basin: Central Andes of Peru. Stoch. Environ. Res. Risk Assess. 2016, 31, 1305-1318. [CrossRef]

10. Marengo, J.A.; Liebmann, B.; Kousky, V.E.; Filizola, N.P.; Wainer, I.C. Onset and End of the Rainy Season in the Brazilian Amazon Basin. J. Clim. 2001, 14, 833-852. [CrossRef]

11. Marengo, J.A.; Fisch, G.F.; Alves, L.M.; Sousa, N.V.; Fu, R.; Zhuang, Y. Meteorological context of the onset and end of the rainy season in Central Amazonia during the Go-Amazon 2014/5. Atmos. Chem. Phys. Discuss. 2017, 17, 7671-7681. [CrossRef]

12. Fu, R.; Yin, L.; Li, W.; Arias, P.A.; Dickinson, R.E.; Huang, L.; Chakraborty, S. Increased dry-season length over southern Amazonia in recent decades and its implication for future climate projection. Proc. Natl. Acad. Sci. USA 2013, 110, 18110-18115. [CrossRef]

13. Raia, A.; Cavalcanti, I.F.d.A. The life cycle of the South American monsoon system. J. Clim. 2008, 21, 6227-6246. [CrossRef]

14. Liebmann, B.; Camargo, S.J.; Seth, A.; Marengo, J.A.; Carvalho, L.M.V.; Allured, D.; Fu, R.; Vera, C.S. Onset and End of the Rainy Season in South America in Observations and the ECHAM 4.5 Atmospheric General Circulation Model. J. Clim. 2007, 20, 2037-2050. [CrossRef]

15. Latinović, D.; Chou, S.C.; Rančić, M.; Medeiros, G.S.; Lyra, A.d.A. Seasonal climate and the onset of the rainy season in western-central Brazil simulated by Global Eta Framework model. Int. J. Climatol. 2019, 39, 1429-1445. [CrossRef]

16. Silva, Y.; Mosquera, K. Inicio de temporada de lluvias en el valle del Mantaro. In Eventos Meteorológicos Extremos (Sequias, Heladas, Lluvias Intensas) en el Valle del Mantaro-Tomo I; Villaverde, M., Ed.; Instituto Geofísico del Perú: Lima, Perú, 2012; pp. 72-75. ISBN 978-612-45795-6-1.

17. Peixoto, J.P.; Oort, A.H. Physics of Climate; Springer-verlag, Ed.; American Institute of Physics: New York, NY, USA, 1992; ISBN 0883187124.

18. Laraque, A.; Ronchail, J.; Cochonneau, G.; Pombosa, R.; Guyot, J.L. Heterogeneous distribution of rainfall and discharge regimes in the Ecuadorian Amazon basin. J. Hydrometeorol. 2007, 8, 1364-1381. [CrossRef]

19. Espinoza Villar, J.C.; Ronchail, J.; Guyot, J.L.; Cochonneau, G.; Naziano, F.; Lavado, W.; De Oliveira, E.; Pombosa, R.; Vauchel, P. Spatio-temporal rainfall variability in the Amazon basin countries (Brazil, Peru, Bolivia, Colombia, and Ecuador). Int. J. Climatol. 2009, 29, 1574-1594. [CrossRef]

20. Instituto Geofísico del Perú. Atlas Climático de Precipitación y Temperatura del Aire en la Cuenca del Río Mantaro; Silva, Y., Ed.; Fondo Editorial CONAM-Instituto Geofísico del Perú: Lima, Perú, 2005; ISBN 9972-824-13-6.

21. Lagos, P.; Silva, Y.; Nickl, E.; Mosquera, K. El Nino-Related precipitation variability in Peru. Adv. Geosci. 2008, 14, 231-237. [CrossRef]

22. Instituto Geofísico del Perú. Manejo de riesgos de desastres ante eventos meteorológicos extremos en el valle del Mantaro-Tomo II; Martínez, A.G., Ed.; Instituto Geofísico del Perú: Lima, Perú, 2012; Volume II, ISBN 978-612-45795-5-4.

23. Instituto Geofísico del Perú. Eventos Meteorológicos Extremos (Sequías, Heladas, Lluvias Intensas) en el Valle del Mantaro-Tomo I; Villaverde, M., Ed.; Instituto Geofísico del Perú: Lima, Perú, 2012; Volume I, ISBN 978-612-45795-6-1.

24. Instituto Geofísico del Perú. Diagnóstico de la Cuenca del Mantaro bajo la Visión del Cambio Climático; Fondo Editorial CONAM-Instituto Geofísico del Perú: Lima, Perú, 2005; ISBN 9972824144.

25. Zhou, J.; Lau, K.-M. Does a Monsoon Climate Exist over South America? J. Clim. 1998, 11, $1020-1040$. [CrossRef]

26. Marengo, J.A.; Liebmann, B.; Grimm, A.M.; Misra, V.; Silva Dias, P.L.; Cavalcanti, I.F.A.; Carvalho, L.M.V.; Berbery, E.H.; Ambrizzi, T.; Vera, C.S.; et al. Recent developments on the South American monsoon system. Int. J. Climatol. 2012, 32, 1-21. [CrossRef]

27. Carvalho, L.M.V.; Jones, C.; Silva, A.E.; Liebmann, B.; Silva Dias, P.L. The South American Monsoon System and the 1970s climate transition. Int. J. Climatol. 2011, 31, 1248-1256. [CrossRef]

28. Nieto-Ferreira, R.; Rickenbach, T.M.; Wright, E.A. The role of cold fronts in the onset of the monsoon season in the South Atlantic convergence zone. Q. J. R. Meteorol. Soc. 2011, 137, 908-922. [CrossRef]

29. Wang, H.; Fu, R. Cross-Equatorial Flow and Seasonal Cycle of Precipitaton over South America. J. Clim. 2002, 15, 1591-1608. [CrossRef] 
30. Vera, C.; Silvestri, G.; Liebmann, B.; González, P. Climate change scenarios for seasonal precipitation in South America from IPCC-AR4 models. Geophys. Res. Lett. 2006, 33. [CrossRef]

31. Garreaud, R.D.; Vuille, M.; Compagnucci, R.; Marengo, J. Present-day South American climate. Palaeogeogr. Palaeoclim. Palaeoecol. 2009, 281, 180-195. [CrossRef]

32. da Silva, A.E.; de Carvalho, L.M.V. Large-scale index for South America Monsoon (LISAM). Atmos. Sci. Lett. 2007, 8, 51-57. [CrossRef]

33. Gan, M.A.; Kousky, V.E.; Ropelewski, C.F. The South America Monsoon circulation and its relationship to rainfall over west-central Brazil. J. Clim. 2004, 17, 47-66. [CrossRef]

34. Gan, M.A.; Rao, V.B.; Moscati, M.C.L. South American monsoon indices. Atmos. Sci. Lett. 2006, 6, $219-223$. [CrossRef]

35. Sulca, J.; Vuille, M.; Silva, Y.; Takahashi, K. Teleconnections between the peruvian central andes and northeast Brazil during extreme rainfall events in austral summer. J. Hydrometeorol. 2016, 17, 499-515. [CrossRef]

36. Avalos, G.; Cubas, F.; Oria, C.; Días, A.; Quispe, N.; Rosas, G.; Cornejo, A.; Solís, O.; Guerra, S. ATLAS CLIMATICO Precipitación y Temperatura del Aire; SENAMHI: Lima, Peru, 2011.

37. Lenters, J.D.; Cook, K.H. On the Origin of the Bolivian High and Related Circulation Features of the South American Climate. J. Atmos. Sci. 1997, 54, 656-678. [CrossRef]

38. Carvalho, L.M.V.; Jones, C.; Liebmann, B. The South Atlantic convergence zone: Intensity, form, persistence, and relationships with intraseasonal to interannual activity and extreme rainfall. J. Clim. 2004, 17, 88-108. [CrossRef]

39. Dee, D.P.; Uppala, S.M.; Simmons, A.J.; Berrisford, P.; Poli, P.; Kobayashi, S.; Andrae, U.; Balmaseda, M.A.; Balsamo, G.; Bauer, P.; et al. The ERA-Interim reanalysis: configuration and performance of the data assimilation system. Q. J. R. Meteorol. Soc. 2011, 137, 553-597. [CrossRef]

40. Adler, R.F.; Huffman, G.J.; Chang, A.; Ferraro, R.; Xie, P.-P.; Janowiak, J.; Rudolf, B.; Schneider, U.; Curtis, S.; Bolvin, D.; et al. The Version-2 Global Precipitation Climatology Project (GPCP) Monthly Precipitation Analysis (1979-Present). J. Hydrometeorol. 2003, 4, 1147-1167. [CrossRef]

41. Garreaud, R.D. Multiscale analysis of the summertime precipitation over the central Andes. Mon. Weather Rev. 1999, 127, 901-921. [CrossRef]

42. Liebmann, B.; Smith, C.A. A description of a complete (interpoled) outgoing longwave radiation dataset. Buletim Am. Meteorol. Soc. 1996, 77, 1275-1277.

43. Hai-Tien, L.; NOAA CDR Program. NOAA Climate Data Record (CDR) of Daily Outgoing Longwave Radiation $(O L R)$, Version 1.2; NOAA National Climatic Data Center: Silver Spring, MD, USA, 2011. Available online: https://data.nodc.noaa.gov/cgi-bin/iso?id=gov.noaa.ncdc:C00875\# (accessed on 11 October 2019).

44. Štěpánek, P. AnClim-Software for Time Series Analysis (for Windows). 2003. Available online: http: //www.climahom.eu/software-solution/anclim (accessed on 15 June 2015).

45. García-Páez, F.; Cruz-Medina, I.R. Fechas de inicios y terminación de la temporada de lluvias en la región Pacífico Norte. Ing. hidráulica en México 2008, 23, 179-188.

46. Meisner, B.N.; Arkin, P.A.; Meisner, B.N.; Arkin, P.A. Spatial and Annual Variations in the Diurnal Cycle of Large-Scale Tropical Convective Cloudiness and Precipitation. Mon. Weather Rev. 1987, 115, 2009-2032. [CrossRef]

47. Kousky, V.E. Pentad Outgoing Longwave Radiation Climatology for the South American Sector. Rev. Bras. Meteorol. 1988, 3, 217-231.

48. Joseph, P.V.; Eischeid, J.K.; Pyle, R.J. Interannual Variability of the Onset of the Indian Summer Monsoon and Its Association with Atmospheric Features, El Niño, and Sea Surface Temperature Anomalies. J. Clim. 1994, 7,81-105. [CrossRef]

49. Mann, H.B. Nonparametric Tests Against Trend. Econometrica 1945, 13, 245-259. [CrossRef]

50. Kendall, M.G. Rank Correlation Methods; Griffin: London, UK, 1975; ISBN 0852641990.

51. Sen, P.K. Estimates of the Regression Coefficient Based on Kendall's Tau. J. Am. Stat. Assoc. 1968, 63, 1379-1389. [CrossRef]

52. Salmi, T.; Määttä, A.; Anttila, P.; Ruoho-Airola, T.; Amnell, T. Detecting Trends of Annual Values of Atmospheric Pollutants by the Mann-Kendall Test and Sen's Slope Estimates-the Excel Template Application MAKESENS; Finnish Meteorological Institute: Helsinki, Finland, 2002; ISBN 9516975631. Available online: https://en.ilmatieteenlaitos.fi/documents/30106/335634754/MAKESENS-Manual_2002.pdf/25bbe1157f7e-4de3-97d8-5a96ac88499f (accessed on 12 July 2017). 
53. Mustapha, A. Detecting Surface Water Quality Trends Using Mann-Kendall Tests and Sen's Slope Estimates. Int. J. Agric. Innov. Res. 2013, 1, 108-114.

54. Trenberth, K.; National Center for Atmospheric Research. The Climate Data Guide: Nino SST Indices (Nino 1+2, 3, 3.4, 4; ONI and TNI). 2019. Available online: https://climatedataguide.ucar.edu/climate-data/nino-sstindices-nino-12-3-34-4-oni-and-tni (accessed on 12 October 2019).

55. Torrence, C.; Compo, G.P. A Practical Guide to Wavelet Analysis. Bull. Am. Meteorol. Soc. 1998, 79, 66-78. [CrossRef]

56. Torrence, C.; Webster, P.J. Interdecadal Changes in the ENSO-Monsoon System. J. Clim. 1999, 12, $2679-2690$. [CrossRef]

57. Grinsted, A.; Moore, J.C.; Jevrejeva, S. Application of the cross wavelet transform and wavelet coherence to geophysical time series. Nonlinear Process. Geophys. 2004, 11, 561-566. [CrossRef]

58. Camberlin, P.; Okoola, R.E. The onset and cessation of the "“ long rains "' in eastern Africa and their interannual variability. Theor. Appl. Climatol. 2003, 75, 43-54. [CrossRef]

59. Camberlin, P.; Diop, M. Application of daily rainfall principal component analysis to the assessment of the rainy season characteristics in Senegal. Clim. Res. 2003, 23, 159-169. [CrossRef]

60. Barreiro, M.; Chang, P.; Saravanan, R. Variability of the South Atlantic convergence zone simulated by an atmospheric general circulation model. J. Clim. 2002, 15, 745-763. [CrossRef]

61. Horel, J.D.; Hahmann, A.N.; Geisler, J.E. An investigation of the Annual Cycle of Convective Activity over the Tropical Americas. J. Clim. 1989, 2, 1388-1403. [CrossRef]

(C) 2020 by the authors. Licensee MDPI, Basel, Switzerland. This article is an open access article distributed under the terms and conditions of the Creative Commons Attribution (CC BY) license (http://creativecommons.org/licenses/by/4.0/). 